\title{
Vitamin D and colorectal cancer: molecular, epidemiological and clinical evidence
}

\author{
Ruoxu Dou ${ }^{1,2}$, Kimmie $\mathrm{Ng}^{1}$, Edward L. Giovannucci ${ }^{3,4,5}$, JoAnn E. Manson ${ }^{3,4,6}$, Zhi Rong Qian ${ }^{1}$ and \\ Shuji Ogino $1,4,7 *$ \\ ${ }^{1}$ Department of Medical Oncology, Dana-Farber Cancer Institute and Harvard Medical School, 450 Brookline Avenue, \\ Boston, MA 02215, USA \\ ${ }^{2}$ Department of Colorectal Surgery, The Sixth Affiliated Hospital, Sun Yat-sen University, 26 Yuancun Erheng Road, \\ Guangdong 510655, People's Republic of China \\ ${ }^{3}$ Department of Nutrition, Harvard T. H. Chan School of Public Health, 677 Huntington Avenue, Boston, MA O2115, USA \\ ${ }^{4}$ Department of Epidemiology, Harvard T. H. Chan School of Public Health, 677 Huntington Avenue, Boston, MA O2115, USA \\ ${ }^{5}$ Department of Medicine, Channing Division of Network Medicine, Brigham and Women's Hospital, Harvard Medical School, \\ 181 Longwood Avenue, Boston, MA 02115, USA \\ ${ }^{6}$ Division of Preventive Medicine, Brigham and Women's Hospital, Harvard Medical School, 900 Commonwealth Avenue, \\ Boston, MA 02115, USA \\ ${ }^{7}$ Department of Pathology, Brigham and Women's Hospital, Harvard Medical School, 75 Francis Street, Boston, MA O2115, USA
}

(Submitted 25 September 2015 - Final revision received 2 February 2016 - Accepted 6 February 2016 - First published online 9 March 2016)

\section{Abstract}

In many cells throughout the body, vitamin D is converted into its active form calcitriol and binds to the vitamin D receptor (VDR), which functions as a transcription factor to regulate various biological processes including cellular differentiation and immune response. Vitamin D-metabolising enzymes (including CYP24A1 and CYP27B1) and VDR play major roles in exerting and regulating the effects of vitamin D. Preclinical and epidemiological studies have provided evidence for anti-cancer effects of vitamin D (particularly against colorectal cancer), although clinical trials have yet to prove its benefit. In addition, molecular pathological epidemiology research can provide insights into the interaction of vitamin D with tumour molecular and immunity status. Other future research directions include genome-wide research on VDR transcriptional targets, gene-environment interaction analyses and clinical trials on vitamin D efficacy in colorectal cancer patients. In this study, we review the literature on vitamin D and colorectal cancer from both mechanistic and population studies and discuss the links and controversies within and between the two parts of evidence.

Key words: 25-Hydroxyvitamin D: P450 hydroxylases: Vitamin D supplementation

Although a well-recognised physiological role of vitamin D is the regulation of $\mathrm{Ca}$ and phosphate metabolism ${ }^{(1)}$, recent studies suggest a much broader range of biological functions of vitamin $\mathrm{D}$, including potential anti-neoplastic effects. Garland \& Garland ${ }^{(2)}$ discovered in 1980 that colon cancer mortality rates in the USA were highest in places where populations were exposed to the least amount of sunlight, and proposed that vitamin D might be a protective factor against colon cancer. Since then, extensive studies have reported anti-neoplastic actions of vitamin $\mathrm{D}$, particularly in colorectal cancer ${ }^{(3,4)}$. If adequate vitamin $\mathrm{D}$ does have a protective effect, ensuring that people have sufficient vitamin D can be an effective way to reduce cancer incidence and mortality $^{(4)}$. In this review, we discuss relevant basic science and preclinical studies, which examined the mechanisms including the regulation of proliferation, differentiation, apoptosis, angiogenesis and immunity. We also discuss epidemiological and human intervention studies and address possible reasons why evidence for an effect of vitamin D supplementation remains inconclusive. In addition, we remark on molecular pathological epidemiology $(\mathrm{MPE})^{(5,6)}$, which can bridge the gap between basic science and human population studies of vitamin $\mathrm{D}$ and colorectal cancer.

We conducted a literature research in the Web of Science database under the topics 'Vitamin D' AND 'Colorectal Neoplasms', and in the PubMed database using the MeSH terms 'Vitamin D'

Abbreviations: 25(OH)D, 25-Hydroxyvitamin D; CDK, cyclin-dependent kinase; miR, microRNA; MPE, molecular pathological epidemiology; VDR, vitamin D receptor.

*Corresponding author: S. Ogino, fax +1 617582 8558, email shuji_ogino@dfci.harvard.edu 
AND 'Colorectal Neoplasms', for papers published in English from January 1995 to November 2015. We manually searched for references cited in the chosen articles and in published reviews.

\section{Source and metabolism of vitamin D}

Vitamin D belongs to a group of steroids known as secosteroids. In humans, the most common forms of vitamin $\mathrm{D}$ are vitamin $\mathrm{D}_{3}$ (cholecalciferol) and vitamin $\mathrm{D}_{2}$ (ergocalciferol); both can be obtained from the diet and from diet supplements. Vitamin $\mathrm{D}_{3}$ can also be synthesised in adequate amounts in the skin, under exposure to sunlight ${ }^{(7)}$. As vitamin $\mathrm{D}$ can be produced in the human body, strictly speaking it is not a vitamin per se, but rather is the precursor to the potent steroid hormone calcitriol (also known as 1,25-dihydroxyvitamin $\mathrm{D}_{3}$ ).

Vitamin D from the skin and diet is activated to calcitriol by two cytochrome P450-mediated hydroxylation steps. The first step takes place mostly in the liver, where the enzyme vitamin D-25hydroxylase (predominantly CYP2R1, cytochrome P450 family 2 subfamily R member 1 ) catalyses the first hydroxylation of vitamin $\mathrm{D}$ at C25. This reaction yields 25-hydroxyvitamin D (25(OH)D) the circulating form with a half-life of 2 weeks - which is used to determine an individual's vitamin D status ${ }^{(7,8)}$. In the second step, $25(\mathrm{OH}) \mathrm{D}$ is metabolised by the enzyme 25-hydroxyvitamin D-1 $\alpha$-hydroxylase (CYP27B1, cytochrome P450 family 27 subfamily $\mathrm{B}$ member 1 ) in the kidneys and certain extrarenal sites to yield the active form calcitriol ${ }^{(9)}$. Calcitriol then performs its biological functions, inhibits CYP27B1 activity ${ }^{(10)}$ and induces expression of the enzyme 25-hydroxyvitamin D-24-hydroxylase (CYP24A1, cytochrome P450 family 24 subfamily A member 1), which catabolises $25(\mathrm{OH}) \mathrm{D}$ and calcitriol into biologically inactive forms (Fig. 1) ${ }^{(11)}$.

\section{Mechanism of calcitriol action}

Calcitriol exerts its biological effects by binding and activating the nuclear vitamin D receptor (VDR) and regulating gene expres$\operatorname{sion}^{(3,12)}$. The binding of calcitriol induces a conformational change in VDR that allows the receptor to dimerise with the retinoid X receptor (RXR); this heterodimer specifically docks on vitamin D response elements (VDRE) in the promoter regions of target genes ${ }^{(13)}$. The conformational change of VDR also recruits the co-activator and detaches the co-repressor to acetylate nucleosome histones and unravel DNA, thus enabling transcription (Fig. 2(a)) $)^{(14)}$.

Calcitriol-dependent repression of gene transcription is documented for the $C Y P 27 B 1^{(15)}$ and $P T H$ (parathyroid hormone) ${ }^{(16)}$ genes. Haussler et al. ${ }^{(17)}$ postulated that VDRmediated repression initiates with the docking of liganded VDR-RXR on a negative VDRE in the promoter regions of target genes, which then conforms liganded VDR such that it binds the co-repressor rather than the co-activator (Fig. 2(b)).

In addition to its genomic actions that occur over a period of hours or days, calcitriol also rapidly initiates many biological responses $^{(18)}$. For instance, calcitriol can bind with a plasma membrane VDR of the intestinal epithelial cells and cause the coupled opening of $\mathrm{Ca}^{2+}$ channels, resulting in the rapid hormonal

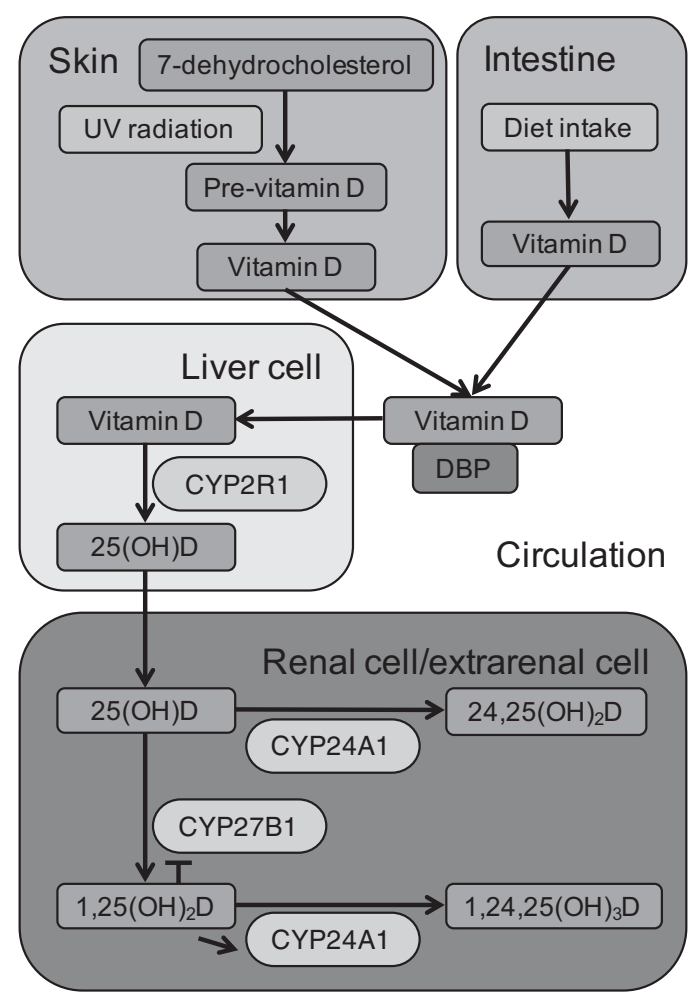

Fig. 1. The metabolism of vitamin $D$ in human body. Vitamin $D$ that is taken up via the diet, or synthesised from 7-dehydrocholesterol by the skin following UV exposure, binds to vitamin D-binding protein (DBP) in the circulation and is transported to the liver. Vitamin D is hydroxylated at C25 by CYP2R1 in the liver to 25-hydroxyvitamin $\mathrm{D}(25(\mathrm{OH}) \mathrm{D})$, the major circulating form of vitamin $\mathrm{D}$ in the human body. In the kidney and some extrarenal sites, $25(\mathrm{OH}) \mathrm{D}$ is further hydroxylated at $\mathrm{C} 1$ by CYP27B1 into 1,25-dihydroxyvitamin $\mathrm{D}_{3}\left(1,25(\mathrm{OH})_{2} \mathrm{D}\right)$ (calcitriol), the bioactive form. Both $25(\mathrm{OH}) \mathrm{D}$ and $1,25(\mathrm{OH})_{2} \mathrm{D}$ are deactivated by CYP24A1 through additional hydroxylation at C24. Both CYP27B1 and CYP24A1 are regulated by calcitriol.

stimulation of intestinal Ca transport (transcaltachia) within minutes ${ }^{(19,20)}$. Furthermore, the binding of calcitriol with membrane VDR may engage in cross-talk with the classical VDR pathway to modulate gene expression, possibly through $\mathrm{Ca}^{2+}$ influx activation of the $\mathrm{Ca}^{2+}$ messenger system such as protein kinase $\mathrm{C}^{(3)}$.

\section{Vitamin D metabolism in colorectal cancer}

The response of cancer cells to calcitriol depends not only on VDR expression but also on the intracellular concentrations of calcitriol $^{(21,22)}$. Intracellular calcitriol concentrations are determined by the circulating concentrations of $25(\mathrm{OH}) \mathrm{D}$ and calcitriol, and by the activity of CYP27B1 and CYP24A1 within the cell. CYP27B1 and CYP24A1 were previously known as enzymes within the kidney, but are now also found in extrarenal sites including the colon ${ }^{(23,24)}$. As described below, the levels of CYP27B1, CYP24A1 and VDR in colorectal cancer cells are studied in relation to differentiation and response to treatment.

\section{CYP27B1}

CYP27B1, as the synthesising enzyme of calcitriol, is normally expressed at low levels in the colon ${ }^{(25,26)}$. In well-differentiated 
(a)

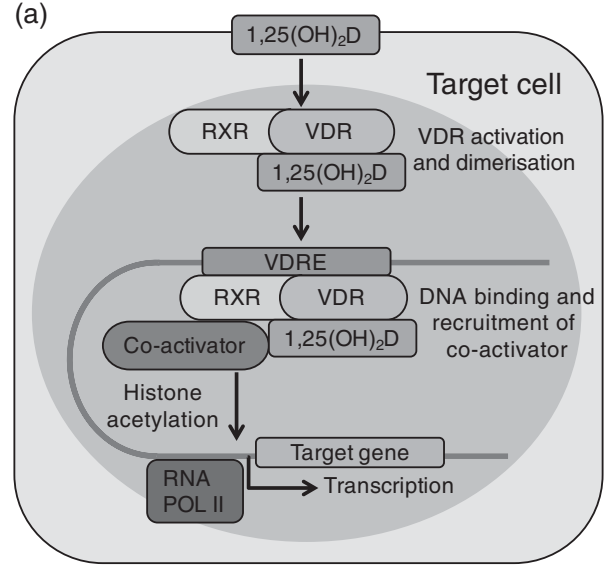

(b)

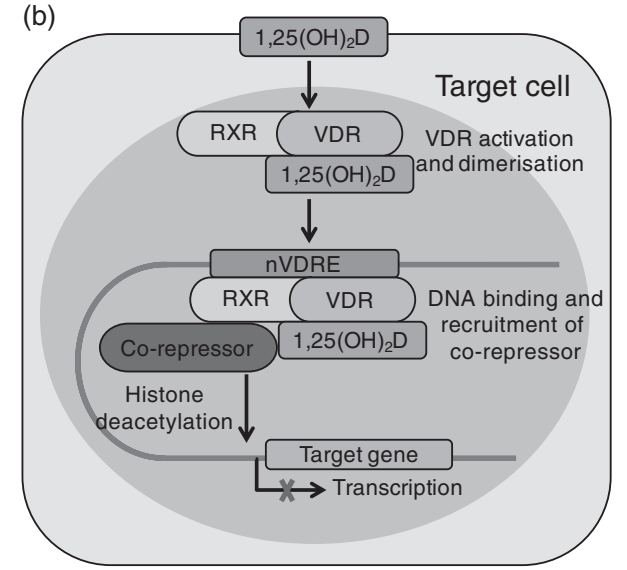

Fig. 2. The mechanism of calcitriol $\left(1,25(\mathrm{OH})_{2} \mathrm{D}\right)$ action through vitamin $\mathrm{D}$ receptor $(\mathrm{VDR})$. Calcitriol binds and activates nuclear VDR, which then dimerises with retinoid $X$ receptor (RXR). (a) Transcriptional activation involves the VDR-RXR heterodimer binding with vitamin $D$ response element (VDRE) and recruitment of histone acetyltransferase co-activator. (b) Transcriptional depression involves VDR-RXR binding with negative VDRE (nVDRE) and recruitment of histone deacetylase co-repressor. RNA POL II, RNA polymerase II.

and moderately differentiated colorectal cancer samples, expression of CYP27B1 is elevated, whereas in poorly differentiated colorectal cancer samples the expression is repressed $^{(25-28)}$. Ogunkolade et al. ${ }^{(29)}$ reported that CYP27B1 mRNA expression levels are similar in colorectal cancer samples and in healthy colon samples, but are decreased in adjacent normal colon mucosa, $10 \mathrm{~cm}$ from the tumour border; this finding suggests that CYP27B1 expression in adjacent colon cells is regulated by the tumour, or that low expression of CYP27B1 in the colon is a risk for carcinogenesis. Bareis et $a l .{ }^{(30)}$ showed that the slowly dividing, highly differentiated colorectal cancer cell line Caco-2/15 responds in a dose-dependent manner to epidermal growth factor (EGF) or calcitriol by up-regulating the expressions of VDR and CYP27B1, whereas highly proliferative, less-differentiated cell lines (Caco-2/AQ, COGA-1A and COGA-1E) show a down-regulation of VDR and CYP27B1 after EGF or calcitriol treatment. Although definite in vivo evidence is lacking, local production of calcitriol in the colon has been indirectly suggested by human studies. The serum concentration of $25(\mathrm{OH}) \mathrm{D}$, rather than that of calcitriol, was inversely associated with colonic epithelial cell proliferation in a chemoprevention study ${ }^{(31)}$. Wagner et al. ${ }^{(32)}$ showed a positive correlation between serum and colon calcitriol concentrations ( $r$ 0.58, $P=0.0008)$, with a positive colon calcitriol intercept $(21.5 \mathrm{pmol} / \mathrm{kg}$, $P<0.001)$ at zero serum calcitriol, supporting the notion of synthesis of calcitriol within the colon. To summarise, elevated CYP27B1 expression suggests possible benefit from treatment with vitamin $\mathrm{D}$, especially in well-differentiated and moderately differentiated tumours, whereas the relatively low expression of CYP27B1 in poorly differentiated colorectal cancer indicates a mechanism of resistance of the cancer cells to calcitriol actions.

\section{CYP24A1}

As the main enzyme determining the biological half-life of calcitriol, CYP24A1 is found in low levels in normal human colon mucosa and in colorectal adenomas, but in elevated levels in the majority of adenocarcinomas ${ }^{(33)}$. CYP24A1 mRNA expression is also increased in poorly differentiated and latestage colorectal cancers, compared with well-differentiated, early-stage tumours ${ }^{(28)}$. Anderson et al. ${ }^{(34)}$ showed that CYP24A1 mRNA expression is not only significantly upregulated in human HT29 cells but also profoundly stimulated by calcitriol treatment, abrogating the anti-proliferative effect of calcitriol. Kosa et al. ${ }^{(35)}$ also observed that CYP24A1 mRNA is induced by calcitriol treatment in Caco-2 - a human colon adenocarcinoma cell line. Cell viability and proliferation are not influenced by calcitriol alone, but are markedly reduced when calcitriol is co-administered with KD-35 - a CYP24A1 inhibitor. Together, these findings suggest that CYP24A1 exhibits a potent negative-feedback effect, and that inhibition of CYP24A1 may be a good strategy for enhancing the anti-tumour effect of calcitriol.

\section{Vitamin $D$ receptor}

As the major receptor to mediate the biological effects of calcitriol, VDR is present in most cells of the human body, and is especially abundant in intestinal epithelial cells ${ }^{(36)}$. VDR expression is increased in adenoma and in well-differentiated or moderately differentiated colorectal cancer tissues, but is decreased in poorly differentiated tumours, and is negligible in metastatic lymph nodes ${ }^{(27,37)}$. Palmer et al. ${ }^{(38)}$ discovered that the transcription factors SNAI1 (snail family zinc finger 1 ) and SNAI2 (snail family zinc finger 2) repress VDR expression in SW480-ADH cells and block the anti-tumour action of the calcitriol analogue EB1089. RNA expressions of SNAI1 and SNAI2 are up-regulated in human colorectal cancers, and are inversely correlated with VDR mRNA expression ${ }^{(38,39)}$. These findings suggest that high levels of SNAI1 and SNAI2 are a probable cause for VDR down-regulation and for vitamin D unresponsiveness in advanced colorectal cancer, and that vitamin D therapy may not be a good treatment choice for patients who overexpress SNAI1 and SNAI2. 


\section{Anti-cancer actions of vitamin D on colorectal cancer}

The anti-cancer effects of calcitriol are mostly studied in vitro by binding to the VDR and causing transcriptional activation and repression of the target genes. Given the pivotal role of nuclear VDR as a transcriptional regulator, researchers have investigated the genome-wide targets of calcitriol-stimulated VDR in human cells by chromatin immunoprecipitationsequencing (ChIP-Seq). In one such study profiling human lymphoblastoid cells, VDR-binding sites were significantly enriched near colorectal cancer-associated genes identified from genome-wide association studies ${ }^{(40)}$. Meyer et al. $^{(41)}$ performed ChIP-Seq for VDR/RXR on the human colorectal cancer cell LS180, and identified FOS (FBJ murine osteosarcoma viral oncogene homolog) and $M Y C$ (v-myc avian myelocytomatosis viral oncogene homolog) among the target genes. In addition, several transcription factors regulated by calcitriol subsequently amplify and diversify the transcriptional output ${ }^{(42)}$. The most studied anti-cancer effects of calcitriol are listed below.

\section{Proliferation}

Previous studies have established VDR as a biomarker for vitamin D-mediated inhibition of human colon cancer cell growth $^{(43)}$. The anti-proliferative effect of vitamin $\mathrm{D}$ on colorectal cancer involves multiple pathways. In Caco-2 cells, calcitriol and its analogues (F6-D3, ZK 156718 and BGP-13) increase the expressions of the cyclin-dependent kinase (CDK) inhibitors CDKN1A (cyclin-dependent kinase inhibitor 1A (p21, Cip1)) and CDKN1B (cyclin-dependent kinase inhibitor 1B (p27, Kip1)), which inhibit CDK2 and CDK6, leading to G1 phase arrest $^{(44-46)}$. Calcitriol also results in the activation of latent transforming growth factor- $\beta 1$ (TGFB1) in Caco- 2 cells, and sensitises these cells to the growth inhibitory effects of TGFB1 $^{(47)}$. Synthetic low-calcemic vitamin D analogues (EB1089 and CB1093) decrease proliferation of HT29 human cancer cells by inhibiting the secretion of insulin-like growth factor 2 (IGF2) and by inducing the insulin-like growth factor-binding protein- 6 , which sequesters IGF2 with high affinity ${ }^{(48)}$. Calcitriol also counteracts EGF-stimulated Caco- 2 cell growth by markedly decreasing epidermal growth factor receptor expression ${ }^{(49)}$.

\section{Differentiation}

Calcitriol has multiple pro-differentiation effects in colorectal cancer cells. The classic marker for differentiation is the expression of alkaline phosphatase, which is found along the brush border of the colon mucosa but is poorly expressed in proliferating colorectal cancer cells. Calcitriol and its analogues (ZK 156718 and EB1089) increase the activity of alkaline phosphatase in colorectal adenoma cell lines (RG/C2 and AA/ C1) and colorectal cancer cells (Caco-2, PC/JW, HT29 and SW620 $)^{(45,50)}$. Chen et al. ${ }^{(51)}$ reported that calcitriol increases alkaline phosphatase activity in Caco-2 cells by stimulating activator protein-1 (FOS/JUN (jun proto-oncogene)) activation, which is accomplished via a protein kinase $\mathrm{C} \alpha$ - and mitogenactivated protein kinase (MAPK)-dependent mechanism.

Apart from affecting the expression of alkaline phosphatase, calcitriol also induces the expression of E-cadherin (CDH1, cadherin 1) and other adhesion proteins, causing $\beta$-catenin (CTNNB1, catenin beta 1) to translocate from the nucleus to E-cadherin complexes at the plasma membrane in the human colon cancer SW480-ADH cell line ${ }^{(52,53)}$; similar effect on Cdh1 has been observed in an $A p c^{\mathrm{min} /+}$ (adenomatous polyposis coli) mouse model ${ }^{(54)}$. Meanwhile, ligand-activated VDR competes with the $\mathrm{T}$ cell-specific transcription factor 7-like 2 (TCF7L2) for CTNNB1 binding and represses downstream gene expression in SW480-ADH cells ${ }^{(52)}$. Calcitriol-VDR also inhibits CTNNB1 activity in Caco-2 cells, and the inhibition is enhanced by wild-type APC ${ }^{(55)}$. Finally, the WNT (wingless-type MMTV integration site family) antagonist DKK1 (dickkopf WNT signaling pathway inhibitor 1) is induced by calcitriol in association with E-cadherin in SW480-ADH cells ${ }^{(56)}$. As a result, calcitriol and its analogues inhibit the WNT/CTNNB1 pathway and the activation of its target genes in colorectal cancer cells; this in turn contributes to the inhibition of cell proliferation and to the maintenance of the differentiated phenotype.

\section{Apoptosis}

Calcitriol induces apoptosis in colorectal adenoma and colorectal cancer by up-regulating the pro-apoptotic proteins BAK1 (BCL2-antagonist/killer 1) and BAX (BCL2-associated X protein) and by down-regulating the expressions of anti-apoptotic proteins BAG1, BIRC5 (baculoviral IAP repeat containing 5) and BCL2 (B-cell CLL/lymphoma 2). In two colorectal adenoma and three colorectal cancer cell lines, calcitriol and the vitamin D analogue EB1089 induced p53-independent apoptosis in a dose-dependent manner, and the levels of the pro-apoptotic protein BAK1 were consistently increased in all the cell lines examined ${ }^{(50)}$. Barnes et al. ${ }^{(57)}$ showed that EB1089 induces apoptosis in a colorectal adenoma $\mathrm{S} / \mathrm{RG} / \mathrm{C} 2$ cell line by re-distributing the anti-apoptotic protein BAG1 from the nucleus to the cytoplasm. Liu et al. ${ }^{(58)}$ discovered that calcitriol suppresses the expression of BIRC5 (survivin) and promotes a cytotoxic response to 5-fluorouracil in human colon cancer cells (CBS, Moser, Caco-2 and HCT116) in a Ca-sensing receptor (CASR)-dependent manner, possibly by binding the VDRE in CASR promoters ${ }^{(59,60)}$. In an Apc ${ }^{1638 N /+}$ mouse model of intestinal cancer, a western-pattern diet decreased the expression of the pro-apoptotic protein BAX and increased the expression of the anti-apoptotic protein BCL2; treatment with vitamin $\mathrm{D}$ and Ca reverses these effects of the western-style diet and markedly inhibits tumour growth ${ }^{(61)}$. In a human colorectal cancer xenograft model in nude mice, treatment with the vitamin D analogues BGP-13 and BGP-15 activated cell apoptosis ${ }^{(46)}$. However, the pro-apoptotic effect of calcitriol appears to be not always true: Stambolsky et al. ${ }^{(62)}$ reported that mutant TP53 (tumor protein p53) is recruited to VDR-regulated genes and converts calcitriol into an antiapoptotic agent in SW480 cells. Thus, TP53 mutation status might be a predictive marker for vitamin $\mathrm{D}$ treatment response.

\section{Angiogenesis}

Calcitriol also inhibits angiogenesis. Mantell et al. ${ }^{(63)}$ showed that calcitriol significantly inhibits the sprouting and elongation 
of vascular endothelial growth factor A (VEGFA)-induced endothelial cells in a dose-dependent manner. In human colorectal cancer SW480 cells, calcitriol treatment for $24 \mathrm{~h}$ at $0 \cdot 1$ and $1 \mu \mathrm{m}$ decreases the expression of hypoxia-inducible factor- $1 \alpha$ and at $1 \mu \mathrm{m}$ inhibits the secretion of VEGFA under conditions of hypoxia $^{(64)}$. However, Fernandez-Garcia et al. ${ }^{(65)}$ reported that calcitriol increases the levels of VEGFA and the anti-angiogenic factor thrombospondin 1, leading to a minimal balanced change in the angiogenic potential of SW480-ADH cells. Calcitriol also represses the expression of DKK4 (dickkopf WNT signaling pathway inhibitor 4) in SW480-ADH cells; DKK4 is induced by the TCF7L2/CTNNB1 pathway and enhances the migratory, invasive and pro-angiogenic potential of colorectal cancer $^{(66)}$. In a rat model of colon tumourigenesis induced by azoxymethan, intraperitoneal administration of calcitriol significantly reduced the incidence of colon tumours and also decreased the level of VEGFA and microvessel counts in tumours, suggesting that anti-angiogenesis is a mechanism for the anti-tumourigenic effect of vitamin $D^{(67)}$.

\section{Immune modulation}

Calcitriol modulates innate and adaptive immunity in the colon $^{(68)}$. Calcitriol induces the expression of the cathelicidin anti-microbial peptide, a major component of the innate immune system, in HT29 cells ${ }^{(69)}$. Lithocholic acid, a secondary bile acid and a vitamin $\mathrm{D}$ analogue, decreases NF- $\kappa \mathrm{B}$ activity via the VDR in colonic cancer cells (Caco-2 and HT29C19A) ${ }^{(70)}$. CYP27B1-knockout mice show increased IL1 and IL17 expressions in the colon and are more susceptible to colitis compared with heterozygote controls ${ }^{(71)}$. In a Smad $^{-1-}$ mouse model of bacteria-induced colitis, increased dietary vitamin D suppressed MAPK and NF- $\kappa$ B activation, severity of colitis and incidence of intestinal cancer ${ }^{(72)}$. In addition, calcitriol has effects on several immune cell types including dendritic cells, B cells and $\mathrm{T}$ cells throughout the human body ${ }^{(73)}$. Specifically, the $V d r$-knockout mouse model showed that VDR is required for the maturation and proliferation of intestinal CD8 $\alpha \alpha^{+}$ intra-epithelial lymphocytes ${ }^{(74)}$, which might have a regulatory role within the gut ${ }^{(75)}$. On the other hand, the effect of calcitriol and the level of expression of VDR may both be affected by the immune environment of the colon: in human colon ductal epithelium, VDR expression is considerably decreased in patients with ulcerative colitis and is even lower in patients with colitis-associated colorectal cancer ${ }^{(76)}$. In line with this, treatment with TNF and IL-6 leads to decreased expression of CYP27B1 in colonic epithelial COGA-1A cells ${ }^{(77)}$.

Recent studies have shown interactions between gut microbiota and immunity in colon carcinogenesis ${ }^{(78-80)}$, and vitamin D has been reported to regulate the gut microbiome. In a dextran sodium sulphate-induced colitis model, mice on vitamin D-deficient diet showed more prominent symptoms of colitis and elevated concentrations of bacteria compared with mice on vitamin D-sufficient diet ${ }^{(81)}$. Similarly, in the same colitis model, Ooi et al. ${ }^{(82)}$ showed that Cyp27b1-knockout mice had higher concentrations of the Helicobacter species in the faeces and more severe symptoms of colitis compared with wild-type littermates. In addition, calcitriol supplementation $(1.25 \mu \mathrm{g} / 100 \mathrm{~g}$ diet $)$ to
Cyp27b1-knockout mice reduced Helicobacter numbers and colitis severity ${ }^{(82)}$. Given the data from mouse models, it would be interesting to investigate changes in the human gut microbiome after vitamin D supplementation.

\section{MicroRNA}

MicroRNAs (miR) are implicated in the anti-neoplastic influence of vitamin $\mathrm{D}^{(12)}$. Alvarez-Diaz et al. ${ }^{(83)}$ reported that $m i R-22$ is induced by calcitriol in a time-, dose- and VDR-dependent manner in multiple human colorectal cancer cell lines. Specifically, in SW480-ADH and HCT116 cells that express VDR, $m i R-22$ is required for the anti-proliferative and anti-migratory effects of calcitriol, and regulates the expression of several target genes of calcitriol. Consistently, miR-22 expression is associated with $V D R$ expression in human colorectal cancer samples, suggesting that $m i R-22$ has a role in the VDR-mediated anti-tumour effect of vitamin D.

Padi et al. ${ }^{(84)}$ found that calcitriol up-regulates $m i R-627$, which in turn mediates the anti-growth effect of calcitriol in HT29 cells; they reported that miR-627 down-regulates the expression of KDM3A (lysine demethylase 3A, a histone demethylase), increases methylation of histone H3K9, and thereby suppresses the expression of proliferative factors such as GDF15 (growth differentiation factor 15). This same effect of miR-627 is also found in the HCT116 xenograft model of nude mice ${ }^{(84)}$. Collectively, these findings suggest that enhancing the effect of $m i R-627$, or suppressing its target KDM3A, has the same anti-tumour effect as does vitamin D, and may bypass the side-effects of hypercalcaemia.

\section{Vitamin D in animal models of colorectal cancer}

Studies in various animal models of colorectal cancer support a protective role of vitamin D. A western-style diet (high in fat and low in vitamin $\mathrm{D}$ and $\mathrm{Ca}$ ) induces benign and malignant tumours in various mouse models of intestinal tumourigenesis, and supplementation with vitamin D plus Ca produces a significant decrease in the incidence and multiplicity of colon tumours ${ }^{(85)}$. In murine models of colorectal carcinogenesis induced by exogenous carcinogens, administration of calcitriol or vitamin D also impedes the neoplastic process ${ }^{(67,86,87)}$.

Tumour cells implanted into mice are commonly used to evaluate anti-cancer treatments. In a human colorectal cancer (MC26) xenograft model, mice fed a vitamin D-sufficient diet had smaller tumours than those fed a vitamin D-deficient $\operatorname{diet}^{(88)}$; in nude mice, treatment with vitamin $\mathrm{D}$ analogues (BGP-13 and BGP-15) inhibited the growth of human HT29 xenograft $^{(46)}$. Add-on of the vitamin D analogues PRI-2191 and PRI-2205 showed improved anti-tumour effects compared with chemotherapy alone, which included 5-fluorouracil, capecitabine, irinotecan or oxaliplatin ${ }^{(89,90)}$.

Mouse models of intestinal cancer are also generated by introducing specific germ-line mutations. The $\mathrm{ApC}^{+/ \mathrm{min}}$ mice develop more than 100 intestinal tumours per animal, and calcitriol significantly decreases the surface area with polyps in the gastrointestinal tract ${ }^{(54,91)}$. In the $A p c^{+/ 1638 \mathrm{~N}}$ mouse model of 
intestinal cancer, when the animals were fed a western-style diet, adding dietary vitamin D and Ca induced apoptosis of epithelial cells and inhibited tumourigenesis in the intestine ${ }^{(61)}$. A protective effect by vitamin $\mathrm{D}$ was also observed in $\mathrm{Smad}^{-/-}$mice, a model of bacteria-driven colitis and colon cancer when infected with Helicobacter bilis ${ }^{(72)}$. Finally, a $V d r$-knockout mouse model, compared with wild-type and heterozygote mice, showed increased markers of cell proliferation and oxidative stress in the colon descendens ${ }^{(92)}$. Compared with $A p c^{+/ m i n} V r^{+/+}$mice, $A p c^{+/ m i n} \mathrm{Vdr}^{-/-}$mice have increased nuclear Ctnnb1, higher expressions of Ctnnb1/Tcf 712 target genes and larger tumours in the intestine ${ }^{(93)}$, supporting the anti-neoplastic effect of VDR in the colon.

\section{Vitamin $D$ action in human colon and rectum}

Beyond cell lines and animal models, researchers have studied the effects of supplemental vitamin D in the colon and rectum of humans. In a randomised, double-blinded, controlled trial of $2 \times 2$ factorial design, Bostick ${ }^{(94)}$ and colleagues tested the efficacy of $20 \mu \mathrm{g}$ of vitamin D and/or $2 \mathrm{~g}$ of Ca daily for 6 months on subjects with recently diagnosed colorectal adenoma. Normal-appearing rectal mucosa was biopsied, and immunohistochemistry was performed for markers of differentiation and proliferation. A statistically significant increase of expressions in the vitamin $\mathrm{D}$ group relative to the placebo group was found for BAX $(56 \%)^{(95)}$, CDKN1A $(142 \%)^{(96)}$, APC (48\%), CDH1 $(78 \%)^{(97)}$, MSH2 (muts homolog 2; 169\%) ${ }^{(98)}$, CASR $(39 \%)$ and CYP27B1 $(159 \%)^{(99)}$. These findings, in line with preclinical studies, indicate that supplemental vitamin D can favourably modulate multiple biomarkers of colorectal cancer risk in normal colon tissues.

\section{Epidemiological studies of vitamin D and colorectal cancer}

Epidemiological studies have extensively investigated the relationship between vitamin D status and colorectal cancer, not only on the incidence of the disease but also on the survival of its patients. Regarding the surrogates for vitamin D status, the evidence of association is strong for plasma $25(\mathrm{OH}) \mathrm{D}$ concentration but less so for vitamin $\mathrm{D}$ intake. For a better interpretation of the data, the strengths and weaknesses of the surrogates are discussed in the context of study design.

\section{Measurement of vitamin D in human populations}

Determination of the vitamin D status of individuals in population-based studies needs a consideration of both biology and logistics. The plasma concentration of total $25(\mathrm{OH}) \mathrm{D}$, the major circulating metabolite of vitamin $\mathrm{D}$, is commonly used to determine vitamin D status ${ }^{(100)}$. For instance, a $25(\mathrm{OH}) \mathrm{D}$ concentration of $<20 \mathrm{ng} / \mathrm{ml}(50 \mathrm{nmol} / \mathrm{l})$ is considered vitamin D insufficiency $^{(101)}$, and $25(\mathrm{OH}) \mathrm{D}$ concentration of $>150 \mathrm{ng} / \mathrm{ml}$ $(375 \mathrm{nmol} / \mathrm{l})$ may cause vitamin D intoxication ${ }^{(100)}$. However, the association of $25(\mathrm{OH}) \mathrm{D}$ with colorectal cancer may be confounded by other risk factors. For example, both obesity and low physical activity have been associated with lower plasma $25(\mathrm{OH}) \mathrm{D}$ concentrations, as well as with increased colorectal cancer risk ${ }^{(102)}$. Inflammation has been postulated as another confounder based on the assumption that inflammation reduces $25(\mathrm{OH}) \mathrm{D}$ concentrations ${ }^{(103)}$, although there is some evidence against this theory ${ }^{(104)}$. Moreover, especially for cohorts, the time of blood sampling will likely precede the diagnosis of colorectal cancer for a variety of years for different patients, and it might be helpful to have an additional $25(\mathrm{OH}) \mathrm{D}$ measurement that is within a comparable time from diagnosis among all patients ${ }^{(105,106)}$. However, serial blood sampling may not be feasible in many large-scale cohort studies.

Alternatively, dietary or supplementary intakes of vitamin D can be assessed repeatedly with questionnaires. Nevertheless, recall of diet and supplement use is imprecise. Moreover, as skin exposed to sunlight also produces vitamin $\mathrm{D}$, vitamin $\mathrm{D}$ intake does not necessarily represent overall vitamin $\mathrm{D}$ status or the plasma concentration of $25(\mathrm{OH}) \mathrm{D}$. In 3345 subjects of the Women's Health Initiative (WHI) observational study, total vitamin $\mathrm{D}$ intake calculated based on information from questionnaires explained 9\% variance in serum $25(\mathrm{OH}) \mathrm{D}$ concentrations $^{(107)}$.

Recently, a predicted $25(\mathrm{OH}) \mathrm{D}$ score using dietary and lifestyle information collected from questionnaires has been used as a surrogate of vitamin D status ${ }^{(108,109)}$. Using multivariate linear regression, Bertrand et al. ${ }^{(108)}$ derived this score based on known determinants of circulating 25(OH)D, including age, race, UV radiation exposure, vitamin D intake, BMI, physical activity, alcohol intake, postmenopausal hormone use and season of blood collection from more than 4500 participants with available blood samples in three US nationwide cohorts. The predicted score explained $25-33 \%$ variance in plasma $25(\mathrm{OH}) \mathrm{D}$ concentrations in different cohorts. This approach of using information from questionnaires estimates vitamin D status data in cohorts where plasma concentrations are not available, and incorporates not only dietary vitamin $\mathrm{D}$ intake but also non-dietary exposures, which are associated with increased plasma $25(\mathrm{OH}) \mathrm{D}$ concentrations. Of note, the predicted score was derived from the original cohorts, and its application to other cohorts will require further validation.

\section{Plasma concentrations of 25-hydroxyvitamin D and incidence of colorectal cancer}

Table 1 summarises previous studies investigating plasma $25(\mathrm{OH}) \mathrm{D}$ concentrations and incidence of colorectal cancer with at least 300 cases $^{(109-122)}$. Evidence for the association of plasma $25(\mathrm{OH}) \mathrm{D}$ concentration or $25(\mathrm{OH}) \mathrm{D}$ score with lower colorectal cancer incidence is quite strong. To further support this, two meta-analyses reported inverse associations between plasma $25(\mathrm{OH}) \mathrm{D}$ concentration and risk of colorectal adenoma, a well-established precancerous lesion for colorectal cancer $^{(123,124)}$.

By integrating exposure data such as vitamin D status and tumour molecular/immune features of colorectal cancer tissue, $\operatorname{MPE}^{(5,6,125,126)}$ research provides new insights into the relationship between vitamin D and colorectal cancer. Jung et $a l .{ }^{(109)}$ studied the risk of colorectal cancer in relation to the 


\section{N British Journal of Nutrition}

Table 1. Major studies (no. of cases $\geq 300$ ) investigating plasma 25-hydroxyvitamin $\mathrm{D}(25(\mathrm{OH}) \mathrm{D})$ concentrations and incidence of colorectal cancer (Odds ratios, hazard ratios (HR) and $95 \%$ confidence intervals)

\begin{tabular}{|c|c|c|c|c|c|c|c|}
\hline References & Study name & Design & No. of cases & Follow-up (years) & $\begin{array}{l}\text { Association of plasma } 25(\mathrm{OH}) \mathrm{D} \text { and incidence } \\
\text { of colorectal cancer }\end{array}$ & $P_{\text {trend }}$ & $P_{\text {heterogeneity }}$ \\
\hline Wactawski-Wende et al. ${ }^{(110)}$ & WHI & Nested case-control & 322 & 7 & $\begin{array}{l}\text { Highest } v \text {. lowest quartile } \\
\text { OR } 0.40(95 \% \mathrm{Cl} 0.23,0.67)\end{array}$ & 0.02 & \\
\hline Wu et al. ${ }^{(111)}$ & NHS, HPFS & Nested case-control & 372 & NHS 5.5; HPFS 4.4 & $\begin{array}{l}\text { Highest } v \text {. lowest quintile } \\
\text { OR } 0.66(95 \% \text { Cl } 0.42,1.05)\end{array}$ & 0.01 & \\
\hline Otani et al. ${ }^{(112)}$ & JPHC Study & Nested case-control & 375 & 11.5 & $\begin{array}{l}\text { Highest } v \text {. lowest quartile } \\
\text { Male: OR } 0.73(95 \% \mathrm{Cl} 0.35,1.5) \\
\text { Female: OR } 1.1(95 \% \mathrm{Cl} 0.50,2 \cdot 3)\end{array}$ & $\begin{array}{l}0.39 \\
0.74\end{array}$ & \\
\hline Jenab et al. ${ }^{(113)}$ & EPIC & Nested case-control & 1248 & $3 \cdot 8$ & $\begin{array}{l}<25 \mathrm{nmol} / / \text {, OR } 1.32(95 \% \mathrm{Cl} 0.87,2.01) \\
25.0-49.9 \mathrm{nmol} / /, \text { OR } 1.28(95 \% \mathrm{Cl} 1.05,1.56) \\
50.0-74.9 \mathrm{nmol} / / \text {, Ref. } \\
75.0-99.9 \mathrm{nmol} / / \text {, OR } 0.88(95 \% \mathrm{Cl} 0.68,1.13) \\
\geq 100.0 \mathrm{nmol} / / \text {, OR } 0.77(95 \% \mathrm{Cl} 0.56,1.06)\end{array}$ & $<0.001$ & \\
\hline Lee et al. ${ }^{(114)}$ & N/A & Meta-analysis (prospective studies) & 2690 & $\mathrm{~N} / \mathrm{A}$ & $\begin{array}{l}\text { Highest } v \text {. lowest category } \\
\text { OR } 0.66(95 \% \mathrm{Cl} 0.54,0.81) \\
\text { Colon cancer OR } 0.77(95 \% \mathrm{Cl} 0.56,1.07) \\
\text { Rectal cancer OR } 0.50(95 \% \mathrm{Cl} 0.28,0.88)\end{array}$ & $\mathrm{N} / \mathrm{A}$ & $0.20^{*}$ \\
\hline Ma et al. ${ }^{(115)}$ & $\mathrm{N} / \mathrm{A}$ & Meta-analysis (prospective studies) & 2767 & $\mathrm{~N} / \mathrm{A}$ & $\begin{array}{l}\text { Highest } v \text {. lowest category } \\
\text { OR } 0.67(95 \% \mathrm{Cl} 0.54,0.80)\end{array}$ & $N / A$ & \\
\hline Chung et al. ${ }^{(116)}$ & $\mathrm{N} / \mathrm{A}$ & Meta-analysis (prospective studies) & 1127 & $\mathrm{~N} / \mathrm{A}$ & $\begin{array}{l}\text { Each } 10-\mathrm{nmol} / \mathrm{l} \text { increase } \\
\text { OR } 0.94(95 \% \mathrm{Cl} 0.91,0.97)\end{array}$ & $<0.001$ & \\
\hline Neuhouser et al. ${ }^{(117)}$ & WHI & Nested case-control & 310 & 7 & $\begin{array}{l}\text { Highest } v \text {. lowest quartile } \\
\text { OR } 0.22(95 \% \mathrm{Cl} 0.10,0.51)\end{array}$ & 0.003 & \\
\hline English et al. ${ }^{(118)}$ & MCCS & Case-cohort & 563 & 14 & $\begin{array}{l}\text { Highest } v \text {. lowest quartile } \\
\text { OR } 0.82(95 \% \mathrm{Cl} 0.61,1.10)\end{array}$ & 0.20 & \\
\hline Jung et al. ${ }^{(109)}$ & NHS, HPFS & $\begin{array}{l}\text { Prospective cohort, predicted } \\
25(\mathrm{OH}) \mathrm{D}, \mathrm{MPE} \text { (VDR expression) }\end{array}$ & 1059 & 22 & $\begin{array}{l}\text { Highest } v \text {. lowest quintile } \\
\text { HR } 0.52(95 \% \mathrm{Cl} 0.42,0.64) \\
\text { VDR (-) HR } 0.48(95 \% \mathrm{Cl} 0.30,0.78) \\
\text { VDR (+) HR } 0.56(95 \% \mathrm{Cl} 0.42,0.75)\end{array}$ & $\begin{array}{r}<0.001 \\
0.004 \\
<0.001\end{array}$ & $0.22 \dagger$ \\
\hline Anic et al. ${ }^{(119)}$ & ATBC & Nested case-control, male smokers & 428 & $6 \cdot 1$ & $\begin{array}{l}\text { Highest } v \text {. lowest quartile } \\
\text { OR } 1.35(95 \% \mathrm{Cl} 0.91,2.01) \\
\text { DBP low: OR } 1.12(95 \% \mathrm{Cl} 0.65,1.94) \\
\text { DBP high: OR } 1.63(95 \% \mathrm{Cl} 0.94,2.83)\end{array}$ & $\begin{array}{l}0.11 \\
0.98 \\
0.02\end{array}$ & $0.24 \ddagger$ \\
\hline Theodoratou et al. ${ }^{(120)}$ & $\mathrm{N} / \mathrm{A}$ & Meta-analysis & 2764 & $\mathrm{~N} / \mathrm{A}$ & $\begin{array}{l}\text { Highest } v \text {. lowest quartile } \\
\text { OR } 0.70(95 \% \mathrm{Cl} 0.58,0.84)\end{array}$ & 0.0002 & \\
\hline Weinstein et al. ${ }^{(121)}$ & PLCO & Nested case-control & 476 & $5 \cdot 6$ & $\begin{array}{l}\text { Highest } v \text {. lowest quintile } \\
\text { OR } 0.59(95 \% \mathrm{Cl} 0.36,0.95)\end{array}$ & 0.02 & \\
\hline Song et al. ${ }^{(122)}$ & NHS, HPFS & Nested case-control, MPE, (immune reaction) & 318 & NHS 20; HPFS 16 & $\begin{array}{l}\text { Highest } v \text {. lowest tertile } \\
\text { High reaction: OR } 0.10(95 \% \mathrm{Cl} 0.03,0.35) \\
\text { Mild reaction: OR } 0.98(95 \% \mathrm{Cl} 0.62,1.54) \\
\text { Absent reaction: OR } 0.71(95 \% \mathrm{Cl} 0.26,1.95)\end{array}$ & $\begin{array}{c}<0.001 \\
0.93 \\
0.55\end{array}$ & $0.001 \S$ \\
\hline
\end{tabular}

WHI, Women's Health Initiative; NHS, Nurses' Health Study; HPFS, Health Professionals Follow-up Study; JPHC Study, Japan Public Health Center-based Prospective Study; EPIC, European Prospective Investigation into Cancer and Nutrition; Ref., referent values; MCCS, Melbourne Collaborative Cohort Study; ATBC, Alpha-Tocopherol, Beta-Carotene Cancer Prevention Study; VDR, vitamin D receptor; DBP, vitamin D-binding protein; PLCO, Prostate, Lung, Colorectal, and Ovarian Cancer Screening Trial; MPE, molecular pathological epidemiology.

* $P_{\text {heterogeneity }}$ is for colon cancer $v$. rectal cancer.

$\dagger P_{\text {heterogeneity }}$ is for VDR (-) v. VDR (+).

$\S P_{\text {hetergonity }}$ is for high $v$. mild $v$. absent reaction. 
predicted score for 25(OH)D concentration (with 1059 incident cases during the follow-up of 140418 participants). A higher predicted $25(\mathrm{OH}) \mathrm{D}$ score was inversely associated with colorectal cancer risk $(P<0 \cdot 001)$, regardless of VDR expression levels in tumour cells $\left(P_{\text {heterogeneity }}=0.75\right.$ ). Considering the role of vitamin D in the immune system, another MPE study showed that high plasma $25(\mathrm{OH}) \mathrm{D}$ concentration was associated with lower risk of colorectal cancer with high-level immune reaction ( $\left.P_{\text {trend }}<0.001\right)$, but not with risk of tumour with lower-level reaction $\left(P_{\text {trend }}>0.50, P_{\text {heterogeneity }}=0.001\right)^{(122)}$. This statistical analysis of heterogeneity is critical, as the hypotheses address differential effects of vitamin D on subtypes ${ }^{(127,128)}$. These data support the hypothesis that effect of vitamin D might be strong in tumours enriched with immune cells ${ }^{(122)}$, because immune cells in tumour can activate vitamin $\mathrm{D}$, and thereby increase local levels of active vitamin $\mathrm{D}^{(129-131)}$. Although a replication by additional studies is needed, these findings suggest an interplay of vitamin D status and the immune system in inhibiting the tumourigenesis of colorectal cancer. In addition, a possible interaction may exist between vitamin D status and tumour immunity status in colorectal cancer patient survival analyses, requiring further investigation. With complex immune and inflammatory processes suggested to be involved in colorectal cancer progression and regulated by vitamin $\mathrm{D}$, it has been recommended that future epidemiological studies should measure both vitamin D and inflammatory markers, preferably multiple times, and perform mediation analysis ${ }^{(132)}$ to study the role of inflammation as a mediator between vitamin $\mathrm{D}$ and colorectal cancer $^{(68)}$.

\section{Plasma 25-hydroxyvitamin D concentration and survival of colorectal cancer}

Table 2 shows previous studies with at least 300 cases on plasma $25(\mathrm{OH}) \mathrm{D}$ concentration and survival of patients with diagnosed colorectal cancer ${ }^{(133-139)}$. Of note, to reduce potential reverse causation associated with undiagnosed tumours at the time of blood sampling that might lower plasma $25(\mathrm{OH}) \mathrm{D}$ concentrations, the Nurses' Health Study ${ }^{(133,134)}$, the Health Professionals Follow-up Study ${ }^{(133,134)}$ and the European Prospective Investigation into Cancer and Nutrition study ${ }^{(136)}$ measured plasma $25(\mathrm{OH}) \mathrm{D}$ concentration before diagnosis of colorectal cancer, and excluded cases diagnosed within 2 years after blood collection. In contrast, the Study of Colorectal Cancer in Scotland ${ }^{(137)}$ and the Cancer and Leukemia Group B/Southwest Oncology Group $80405^{(139)}$ studies measured $25(\mathrm{OH}) \mathrm{D}$ shortly after diagnosis, a timing more subject to reverse causation. Despite the different timing of blood collection, there is a consistent prognostic association of plasma $25(\mathrm{OH}) \mathrm{D}$ concentration with colorectal cancer patient survival.

\section{Vitamin D intake and incidence of colorectal cancer}

Table 3 lists previous studies exploring the relationship between vitamin D intake and risk of colorectal cancer with at least 500 cases ${ }^{(113,115,140-150)}$. In contrast to the consistent and strong evidence from the studies measuring plasma $25(\mathrm{OH}) \mathrm{D}$, the association between vitamin D intake and incidence of colorectal cancer is conflicting. Nevertheless, a 2011 meta-analysis ${ }^{(115)}$ of prospective studies reported an inverse association between vitamin $\mathrm{D}$ intake and colorectal cancer incidence.

\section{Vitamin D intake and survival of colorectal cancer}

Observational studies on the impact of vitamin D intake in patients with diagnosed colorectal cancer are limited. In a paper published in 2014, Yang et al. ${ }^{(151)}$ included 1111 participants in the Cancer Prevention Study II Nutrition Cohort who were diagnosed with invasive, non-metastatic colorectal cancer. The researchers evaluated associations of $\mathrm{Ca}$, vitamin $\mathrm{D}$ and diary product intakes after colorectal cancer diagnosis with all-cause and colorectal cancer-specific mortality. After a mean follow-up of 7.6 years, both $\mathrm{Ca}$ and milk intakes were inversely associated with all-cause mortality and colorectal cancer-specific mortality, but vitamin $\mathrm{D}$ intake was not associated with either mortality outcomes $^{(151)}$.

\section{Randomised controlled trials}

Randomised placebo-controlled trials are the 'gold standard' in establishing causal association; however, such evidence to date has been inconclusive on the effect of vitamin D on colorectal cancer. The findings and limitations of completed clinical trials are discussed, with a preview of ongoing trials, which might hopefully conclude the controversy.

\section{Completed clinical trials of vitamin D intake and incidence of colorectal cancer}

To date, four completed randomised controlled trials of vitamin $\mathrm{D}$ have a reasonable number of cancer cases (Table 4) ${ }^{(110,152-154)}$. In a substudy of the WHI, 36282 postmenopausal women were given $5 \mu \mathrm{g}$ of vitamin D and $500 \mathrm{mg}$ of Ca twice daily ( $10 \mu \mathrm{g}$ of vitamin D and $1000 \mathrm{mg}$ of Ca daily), or a matching placebo, for an average of 7 years ${ }^{(110)}$. The incidence of invasive colorectal cancer in this study did not differ significantly between women assigned to $\mathrm{Ca}$ plus vitamin $\mathrm{D}$ and those assigned to placebo (168 v. 154 cases, hazard ratio 1.08; 95\% CI $0.86,1.34 ; P=0.51$ ), and tumour characteristics were similar in the two groups. This study has several limitations. First, the modest dose of vitamin $\mathrm{D}$ used in the trial led to only a small rise in plasma $25(\mathrm{OH}) \mathrm{D}$ concentrations ${ }^{(155)}$, which was measured only in a small sample of the study population. Second, the limited compliance in the treatment group and the allowance for the placebo group to take supplements could have further reduced the actual contrast of $25(\mathrm{OH}) \mathrm{D}$ between groups. In fact, as shown in a post hoc analysis of WHI, in 15646 women (43\%) who were not taking personal Ca or vitamin D supplements at randomisation, $\mathrm{Ca}$ and vitamin $\mathrm{D}$ treatment non-significantly reduced the risk of colorectal cancer by $17 \%{ }^{(156)}$. Third, the 7-year follow-up may not be sufficient to show a benefit for the prevention of colorectal cancer, which has a long natural history and a relatively low incidence. 
Table 2. Major studies (no. of cases $\geq 300$ ) investigating plasma 25-hydroxyvitamin $\mathrm{D}(25(\mathrm{OH}) \mathrm{D})$ concentrations and survival of patients with diagnosed colorectal cancer (CRC) (Hazard ratios (HR) and $95 \%$ confidence intervals)

\begin{tabular}{|c|c|c|c|c|c|c|c|c|}
\hline References & Study name & Design and timing of blood draw & No. of cases & All deaths & CRC deaths & Follow-up (years) & $\begin{array}{l}\text { Association of plasma } 25(\mathrm{OH}) \mathrm{D} \text { and } \\
\text { mortality of CRC }\end{array}$ & $P_{\text {trend }}$ \\
\hline $\mathrm{Ng}$ et al..$^{(133)}$ & NHS, HPFS & Prospective cohort, prediagnosis & 304 & 123 & 96 & 6.5 & $\begin{array}{l}\text { Highest } v \text {. lowest quartile } \\
\text { CRC specific: HR } 0.61(95 \% \text { Cl } 0.31,1.19) \\
\text { All-cause: HR } 0.52(95 \% \text { Cl 0.29, } 0.94)\end{array}$ & $\begin{array}{l}0.23 \\
0.02\end{array}$ \\
\hline $\mathrm{Ng}$ et $a .^{(134)}$ & NHS, HPFS & Prospective cohort, predicted $25(\mathrm{OH}) \mathrm{D}$ & 1017 & 283 & 119 & $9 \cdot 7$ & $\begin{array}{l}\text { Highest } v \text {. lowest quintile } \\
\text { CRC specific: HR } 0.50(95 \% \mathrm{Cl} 0.26,0.95) \\
\text { All-cause: HR } 0.62(95 \% \mathrm{Cl} 0.42,0.93)\end{array}$ & $\begin{array}{l}0.02 \\
0.002\end{array}$ \\
\hline $\mathrm{Ng}$ et $a .^{(135)}$ & NCCTG 9741 & Prospective cohort, mCRC postdiagnosis & 515 & 475 & N/A & $5 \cdot 1$ & $\begin{array}{l}\text { Highest } v \text {. lowest quartile } \\
\text { PFS: HR } 1.07(95 \% \mathrm{Cl} 0.81,1.42) \\
\text { All-cause: HR } 0.94(95 \% \mathrm{Cl} 0.72,1.23)\end{array}$ & $\begin{array}{l}0.66 \\
0.55\end{array}$ \\
\hline Fedirko et al. ${ }^{(136)}$ & EPIC & Prospective cohort, prediagnosis & 1202 & 541 & 444 & $6 \cdot 1$ & $\begin{array}{l}\text { Highest } v \text {. lowest quintile } \\
\text { CRC specific: HR } 0.69(95 \% \mathrm{Cl} 0.50,0.93) \\
\text { All-cause: HR } 0.67(95 \% \mathrm{Cl} 0.50,0.88)\end{array}$ & $\begin{array}{l}0.04 \\
0.01\end{array}$ \\
\hline Zgaga et al. ${ }^{(137)}$ & soccs & Prospective cohort postdiagnosis & 1598 & 531 & 363 & 8.9 & $\begin{array}{l}\text { Highest } v \text {. lowest tertile } \\
\text { CRC specific: HR } 0.68(95 \% \mathrm{Cl} 0.50,0.90) \\
\text { All-cause: HR } 0.70(95 \% \mathrm{Cl} 0.55,0.89)\end{array}$ & $\begin{array}{l}0.009 \\
0.003\end{array}$ \\
\hline Maalmi et al. ${ }^{(138)}$ & $\mathrm{N} / \mathrm{A}$ & Meta-analysis (prospective studies) & 2330 & 1214 & 566 & $\mathrm{~N} / \mathrm{A}$ & $\begin{array}{l}\text { Highest } v \text {. lowest category } \\
\text { CRC specific: HR 0.65 (95\% Cl 0.49, 0.86) } \\
\text { All-cause: HR } 0.71(95 \% \mathrm{Cl} 0.55,0.91)\end{array}$ & $\mathrm{N} / \mathrm{A}$ \\
\hline $\mathrm{Ng}$ et al. .139$)$ & CALGB/SWOG 80405 & Prospective cohort, mCRC postdiagnosis & 1043 & $\mathrm{~N} / \mathrm{A}$ & & 7 & $\begin{array}{l}\text { Highest } v \text {. lowest quintile } \\
\text { PFS: HR } 0.80(95 \% \mathrm{Cl} 0.64,1.01) \\
\text { All-cause: HR } 0.67(95 \% \mathrm{Cl} 0.53,0.86)\end{array}$ & $\begin{array}{l}0.02 \\
0.002\end{array}$ \\
\hline
\end{tabular}

NHS, Nurses' Health Study; HPFS, Health Professionals Follow-up Study; NCCTG, North Central Cancer Treatment Group; mCRC, metastatic colorectal cancer; PFS, progression-free survival; EPIC, European Prospective Investigation into Cancer and Nutrition; SOCCS, Study of Colorectal Cancer in Scotland; CALGB, Cancer and Leukemia Group B; SWOG, Southwest Oncology Group. 
Table 3. Major studies (no. of cases $\geq 500$ ) investigating vitamin $D$ intake and incidence of colorectal cancer (CRC) (Odds ratios, relative risks (RR) and $95 \%$ confidence intervals)

\begin{tabular}{|c|c|c|c|c|c|c|}
\hline References & Study name & Design & No. of cases & Follow-up (years) & Association of vitamin D intake and incidence of CRC & $P_{\text {trend }}$ \\
\hline Martinez et al. ${ }^{(140)}$ & NHS & Prospective cohort & 501 & 12 & $\begin{array}{l}\text { Highest } v \text {. lowest quintile } \\
\text { RR } 0.88(95 \% \mathrm{Cl} 0.66,1.16)\end{array}$ & 0.23 \\
\hline Pritchard et al. ${ }^{(141)}$ & Stockholm & Case-control & 569 & $\mathrm{~N} / \mathrm{A}$ & $\begin{array}{l}\text { Highest } v \text {. lowest quartile } \\
\text { Colon cancer: OR } 0.6(95 \% \mathrm{Cl} 0.4,1.0) \\
\text { Rectal cancer: OR } 0.5(95 \% \mathrm{Cl} 0.3,0.9)\end{array}$ & $\begin{array}{l}0.08 \\
0.08\end{array}$ \\
\hline Marcus et al. ${ }^{(149)}$ & $\mathrm{N} / \mathrm{A}$ & Case-control & 512 & $\mathrm{~N} / \mathrm{A}$ & $\begin{array}{l}\text { Highest } v \text {. lowest quintile } \\
\text { Colon cancer: OR } 0.7(95 \% \mathrm{Cl} 0.4,1.1) \\
\text { Rectal cancer: OR } 0.8(95 \% \mathrm{Cl} 0.5,1.5)\end{array}$ & $\begin{array}{l}0.05 \\
0.42\end{array}$ \\
\hline Terry et al. ${ }^{(142)}$ & SMC & Cohort, women & 572 & 11.3 & $\begin{array}{l}\text { Highest } v \text {. lowest quartile } \\
\text { RR } 1.05(95 \% \mathrm{Cl} 0.83,1.33)\end{array}$ & 0.73 \\
\hline McCullough et al. ${ }^{(150)}$ & CPS II & Cohort & 683 & 5 & $\begin{array}{l}\text { Highest } v \text {. lowest quartile } \\
\text { RR } 0.80(95 \% \text { Cl } 0.62,1.02)\end{array}$ & 0.02 \\
\hline Slattery et al. ${ }^{(143)}$ & $\mathrm{N} / \mathrm{A}$ & Case-control & 2306 & $\mathrm{~N} / \mathrm{A}$ & $\begin{array}{l}\text { Highest } v \text {. lowest quartile } \\
\text { Men: OR } 1.08(95 \% \mathrm{Cl} 0.73,1.60) \\
\text { Women: OR } 0.52(95 \% \mathrm{Cl} 0.32,0.85)\end{array}$ & $\mathrm{N} / \mathrm{A}$ \\
\hline Park et al. ${ }^{(144)}$ & Multiethnic Cohort Study & Cohort & 2100 & $7 \cdot 3$ & $\begin{array}{l}\text { Highest } v \text {. lowest quintile } \\
\text { Men: RR } 0.66(95 \% \mathrm{Cl} 0.54,0.81) \\
\text { Women: RR } 0.81(95 \% \mathrm{Cl} 0.66,0.98)\end{array}$ & $\begin{array}{l}0.03 \\
0.80\end{array}$ \\
\hline Mizoue et al..$^{(145)}$ & Fukuoka CRC Study & Case-control & 836 & $\mathrm{~N} / \mathrm{A}$ & $\begin{array}{l}\text { Highest } v \text {. lowest quintile } \\
\text { OR } 0.79(95 \% \mathrm{Cl} 0.56,1.11) \\
\text { Indoor: OR } 0.63(95 \% \mathrm{Cl} 0.36,1.08) \\
\text { Outdoor: OR } 0.94(95 \% \mathrm{Cl} 0.58,1.52)^{*}\end{array}$ & $\begin{array}{l}0.12 \\
0.02 \\
0.86\end{array}$ \\
\hline Ishihara et al. ${ }^{(146)}$ & JPHC Study & Nested case-control & 761 & $7 \cdot 8$ & $\begin{array}{l}\text { Highest } v \text {. lowest quintile } \\
\text { Men: OR } 0.92(95 \% \mathrm{Cl} 0.60,1.42) \\
\text { Women: OR } 1.49(95 \% \mathrm{Cl} 0.86,2.60)\end{array}$ & $\begin{array}{l}0.58 \\
0.26\end{array}$ \\
\hline Lipworth et al. ${ }^{(147)}$ & $\mathrm{N} / \mathrm{A}$ & Case-control & 1953 & $\mathrm{~N} / \mathrm{A}$ & $\begin{array}{l}\text { Highest } v \text {. lowest decile } \\
\text { Colon cancer: OR } 0.69(95 \% \mathrm{Cl} 0.50,0.96) \\
\text { Rectal cancer: OR } 1.22(95 \% \mathrm{Cl} 0.82,1.80)\end{array}$ & $\begin{array}{l}<0.0001 \\
0.70\end{array}$ \\
\hline Huncharek et al. ${ }^{(148)}$ & $\mathrm{N} / \mathrm{A}$ & Meta-analysis (cohorts) & 2813 & $\mathrm{~N} / \mathrm{A}$ & $\begin{array}{l}\text { Highest } v \text {. lowest category } \\
\text { RR } 0.94(95 \% \mathrm{Cl} 0.83,1.06)\end{array}$ & N/A \\
\hline Jenab et al. ${ }^{(113)}$ & EPIC & Nested case-control & 1248 & 3.8 & $\begin{array}{l}\text { Highest } v \text {. lowest quintile } \\
\text { OR } 0.84(95 \% \mathrm{Cl} 0.60,1.17)\end{array}$ & 0.19 \\
\hline Ma et al. ${ }^{(115)}$ & $\mathrm{N} / \mathrm{A}$ & Meta-analysis (prospective studies) & 6466 & $\mathrm{~N} / \mathrm{A}$ & $\begin{array}{l}\text { Highest } v \text {. lowest category } \\
\text { RR } 0.88(95 \% \mathrm{Cl} 0.80,0.96)\end{array}$ & $\mathrm{N} / \mathrm{A}$ \\
\hline
\end{tabular}

NHS, Nurses' Health Study; SMC, Swedish Mammography Cohort; CPS II, Cancer Prevention study II; JPHC Study, Japan Public Health Center-based Prospective Study; EPIC, European Prospective Investigation into Cancer and Nutrition.

* Indoor, subjects engaged in sedentary or standing work (including no job) and no outdoor physical activity at leisure; outdoor, subjects engaged in work with labour or walking or outdoor physical activity at leisure at least of 120 min/week. 
A second completed randomised trial was carried out in the UK, with 2686 participants (2037 men and 649 women) ${ }^{(152)}$. An oral supplement of $2500 \mu \mathrm{g}$ vitamin D or a matching placebo was given every 4 months for 5 years. Over the 5 -year period, twenty-eight and twenty-seven cases of colon cancer were documented in the treatment and control group, respectively, with no association with vitamin D treatment (relative risk 1.02; $95 \%$ CI $0.60,1.74 ; P=0.94)$. This study applied a dosage of vitamin $D$ that had a moderate effect upon the measured plasma $25(\mathrm{OH}) \mathrm{D}$ concentration $(74.3 \mathrm{nmol} / 1$ in the treatment group $v .53 .4 \mathrm{nmol} / 1$ in the control group, $P<0.001)$; nevertheless, it was limited by the small sample size and the short follow-up period.

Two other studies have investigated the association of vitamin D and Ca supplement intake with cancer incidence. The Nebraska trial ${ }^{(153)}$ detected lower incidence of cancer in patients treated with vitamin D plus Ca than with placebo $(P<0.03)$, whereas the Randomised Evaluation of Calcium Or vitamin D trial ${ }^{(154)}$ found no association. However, neither study was designed to detect the association of supplement use with colorectal cancer incidence as the primary end point

In the recently published Vitamin D/Calcium Polyp Prevention trial (Table 4$)^{(157)}$, patients with recently diagnosed adenomas were randomly assigned $25 \mu \mathrm{g}$ of vitamin $\mathrm{D}$ daily or no vitamin $D$ in a factorial design. After 3 or 5 years of treatment, participants given vitamin $\mathrm{D}$ had a mean net increase in serum $25(\mathrm{OH}) \mathrm{D}$ concentrations of $7.83 \mathrm{ng} / \mathrm{ml}$, relative to participants given placebo. Overall, $43 \%$ of the participants had one or more adenomas diagnosed during follow-up, and the adjusted risk ratio for recurrent adenoma was 0.99 (95\% CI 0.89, 1.09) with vitamin $\mathrm{D} v$. no vitamin $\mathrm{D}$.

Two points are worth noting for comparison of this null finding with preexisting epidemiological evidence. First, as the authors admitted, the vitamin D dose in the Polyp Prevention trial ( $25 \mu \mathrm{g}$ daily) was lower than the dose many experts now recommend $^{(158,159)}$, and it was used for a limited time ${ }^{(157)}$. This resulted in a net increase of $7.83 \mathrm{ng} / \mathrm{ml}$ of serum $25(\mathrm{OH}) \mathrm{D}$, in contrast with a generally $>20 \mathrm{ng} / \mathrm{ml}$ difference between the high and low quartiles or quintiles of $25(\mathrm{OH}) \mathrm{D}$ in observational studies $^{(160)}$. Thus, the moderate dose of vitamin D might not cause a change in adenoma incidence that was detectable by the power of this trial. Second, the risk of incidence for recurrent adenoma is not a direct translation of the risk for incident adenoma or colorectal cancer. For instance, in a colorectal cancer screening trial, elevated dietary fibre intake was associated with reduced risk of incident colorectal adenoma and colorectal cancer (OR 0.76 and $0 \cdot 85$, respectively), but not with the risk of recurrent adenoma (OR 1.08) ${ }^{(161)}$. Similarly, a metaanalysis has also shown different associations of higher serum $25(\mathrm{OH}) \mathrm{D}$ with incident or recurrent colorectal adenoma (OR 0.82 or 0.87 for a $20 \mathrm{ng} / \mathrm{ml}$ increase, respectively) ${ }^{(124)}$. Therefore, the null finding should not be generalised to persons without a recent history of colorectal adenoma. On the basis of the clinical literature included in this review, high vitamin D status might have the greatest anti-neoplastic effects early in colorectal carcinogenesis and later in disease progression, but less so in the metastatic stage or adenoma recurrence. 

colorectal cancer

Several randomised controlled trials are under way to study whether vitamin D supplementation reduces the risk of cancer (Table 5) ${ }^{(162)}$. These trials are applying higher dosages of vitamin $\mathrm{D}$ than previous trials, and are measuring baseline and/ or follow-up plasma $25(\mathrm{OH}) \mathrm{D}$ concentrations. For example, the VITamin D and OmegA-3 TriaL study collects baseline blood samples on 17000 participants and follow-up samples on $6000^{(163)}$. In aggregate, these trials have already recruited over 53000 participants, and the first results are expected to be available in 2015 .

\section{Clinical trial of vitamin D intake and survival of colorectal cancer}

Accumulating evidence of the involvement of vitamin $\mathrm{D}$ in cancer progression demands clinical trials for patients diagnosed with colorectal cancer. The study of mortality, rather than incidence, of colorectal cancer will likely require fewer subjects and shorter follow-up. To date, only one clinical trial is registered on ClinicalTrials.gov addressing this question (NCT01516216); it is recruiting 120 participants with previously untreated metastatic colorectal cancer and randomising them into two arms. Together with the standard chemotherapy with FOLFOX and bevacizumab, arm 1 gets $10 \mu \mathrm{g} / \mathrm{d}$ of vitamin D, whereas arm 2 gets a loading dose of $200 \mu \mathrm{g} / \mathrm{d}$ for 2 weeks followed by a maintenance dose of $100 \mu \mathrm{g} / \mathrm{d}$. Although the sample size is small, the study does collect plasma $25(\mathrm{OH}) \mathrm{D}$ concentrations, and thus analyses of the relationships between high-dose vitamin D treatment, 25(OH)D status and prognosis are possible.

\section{Genetic variation, vitamin D status and colorectal cancer}

Heritable factors explain approximately $35 \%$ of the risk of colorectal cancer ${ }^{(164)}$, and contribute substantially to the variability of vitamin D status ${ }^{(165)}$. Thus, genetic variation related to vitamin $\mathrm{D}$ status might have an impact on the risk of colorectal cancer. A genome-wide association study of circulating 25(OH)D concentrations in 33996 individuals has identified SNP loci near four genes including $G C$ (group-specific component, which encodes vitamin D-binding protein), DHCR7 (7-dehydrocholesterol reductase, which can remove the substrate from vitamin D synthesis in skin), CYP2R1 and CYP24A1 ${ }^{(166)}$. To gain insight into the genetic link between vitamin D status and colorectal cancer, Hiraki et al. ${ }^{(167)}$ investigated these four SNP loci in 10061 colorectal cancer cases and 12768 controls, but found no significant association between the loci and risk of colorectal cancer. A similar null finding was reported in another cohort containing 438 colorectal cancer cases $^{(168)}$. Moreover, the four loci do not overlap with the risk variants identified from previous genome-wide association studies for colorectal cancer ${ }^{(169)}$. As the SNP identified by Wang et $a l .{ }^{(166)}$ can explain only a small variation $(1-4 \%)$ in $25(\mathrm{OH}) \mathrm{D}$ concentrations, the reduction in overall colorectal cancer risk by 
increased vitamin D levels due to the SNP might be too small to be detectable. In addition to genes related to vitamin $\mathrm{D}$ metabolism, VDR polymorphism has also been studied with regard to risk of colorectal cancer, although most results are inconclusive $^{(170)}$. Nevertheless, two meta-analyses have shown significant associations of risk for colorectal cancer with two VDR polymorphisms, $B s m I$ (rs1544410) (relative risk (RR) 0.57; $95 \%$ CI 0.36, 0.89 for BBv. bb) ${ }^{(171)}$ and TaqI (rs731236) (OR 1.43; $95 \%$ CI $1.30,1.58$ for $t t v . T T)^{(172)}$, respectively.

As one future direction, the MPE approach may link vitamin-D-related SNP to specific subtypes of colorectal cancer. Another future direction is to investigate interactions between SNP of the vitamin D pathway genes and vitamin D status variables in analyses of colorectal cancer incidence and mortality ${ }^{(173)}$. In addition to such a candidate gene approach, analyses of genome-wide gene-environment interactions with vitamin D status variables may enable us to discover potentially important SNP and pathways for colorectal cancer ${ }^{(169)}$. Next-generation sequencing technologies, with greater depth and finer resolution, will draw a broader picture for the targets and interacting factors of vitamin D and VDR, and relate them with specific diseases including colorectal cancer ${ }^{(174)}$.

\section{Conclusion}

Since Garland \& Garland $^{(2)}$ proposed vitamin D for colon cancer prevention 25 years ago, functional studies on vitamin D or its analogues have provided supportive evidence for its anti-tumour effect in colorectal cancer. Evidence from both in vitro and in vivo experiments suggests that anti-proliferation, pro-differentiation, pro-apoptosis, anti-angiogenesis, immune modulation and $\mathrm{miR}$ regulation are involved in the anti-tumour effect of vitamin D. Recent studies also have explored the local expressions and impacts of vitamin D-metabolising enzymes and VDR, which may lead to the discovery of predictive biomarkers for vitamin $\mathrm{D}$ treatment response.

Epidemiological studies have consistently demonstrated a strong inverse association of plasma $25(\mathrm{OH}) \mathrm{D}$ concentration with colorectal cancer incidence and mortality. The MPE approach is valuable in generating hypotheses on potential mechanisms of the observed protective effect of vitamin $\mathrm{D}$, and in identifying molecular pathological signatures as predictive markers for benefit from vitamin $\mathrm{D}$. On the other hand, the effect of vitamin D intake on colorectal cancer prevention is controversial, largely due to the following reasons: the slow development of colorectal cancer, the confounding effects caused by sunlight exposure, outdoor physical activity, BMI, dairy and $\mathrm{Ca}$ intakes, etc. in observational studies, and the suboptimal dosage of vitamin D applied in previous clinical trials. Ongoing large randomised controlled trials with high-dose vitamin D treatment are promising to tackle these problems and decide the value of vitamin D supplementation. Meanwhile, clinical trials of vitamin D on colorectal cancer survival are scarce and logistically more feasible, suggesting a new direction for future studies. Finally, next-generation sequencing and studies of genome-wide gene-environment interactions will likely shed more light on the mechanisms of association between vitamin D and colorectal cancer.

\section{Acknowledgements}

The authors thank Sonal Jhaveri, who is supported by the Dana-Farber Cancer Institute, for editing the manuscript.

This work was supported by US National Institutes of Health grants (R01 CA151993 and R35 CA197735 to S. O.; U01 CA138962 to J. E. M.; K07 CA148894 to K. N.). The content is solely the responsibility of the authors and does not necessarily represent the official views of the National Institutes of Health. The funders had no role in the study design, data collection and analysis, decision to publish or preparation of the manuscript.

R. D. and Z. R. Q. designed the research; R. D. and S. O. wrote the paper; Z. R. Q., K. N., E. L. G. and J. E. M. reviewed the paper; and R. D. and S. O. had primary responsibility for the final content. All authors read and approved the final manuscript.

J. E. M. and colleagues at Brigham and Women's Hospital, Harvard Medical School, are recipients of funding from the National Institutes of Health to conduct the VITamin D and OmegA-3 TriaL, a large-scale randomised trial of vitamin D and $n-3$ in the prevention of cancer and CVD (U01 CA138962). The other authors declare that they have no conflicts of interest.

\section{References}

1. Holick MF (2006) The role of vitamin D for bone health and fracture prevention. Curr Osteoporos Rep 4, 96-102.

2. Garland CF \& Garland FC (1980) Do sunlight and vitamin D reduce the likelihood of colon cancer? Int J Epidemiol $\mathbf{9}$, $227-231$.

3. Deeb KK, Trump DL \& Johnson CS (2007) Vitamin D signalling pathways in cancer: potential for anticancer therapeutics. Nat Rev Cancer 7, 684-700.

4. Feldman D, Krishnan AV, Swami S, et al. (2014) The role of vitamin D in reducing cancer risk and progression. Nat Rev Cancer 14, 342-357.

5. Ogino S, Chan AT, Fuchs CS, et al. (2011) Molecular pathological epidemiology of colorectal neoplasia: an emerging transdisciplinary and interdisciplinary field. Gut 60, 397-411.

6. Ogino S \& Stampfer M (2010) Lifestyle factors and microsatellite instability in colorectal cancer: the evolving field of molecular pathological epidemiology. J Natl Cancer Inst 102, 365-367.

7. Holick MF (2006) Resurrection of vitamin D deficiency and rickets. J Clin Invest 116, 2062-2072.

8. Ponchon G \& DeLuca HF (1969) The role of the liver in the metabolism of vitamin D. J Clin Invest 48, 1273-1279.

9. Fraser DR \& Kodicek E (1970) Unique biosynthesis by kidney of a biological active vitamin D metabolite. Nature 228, 764-766.

10. Young MV, Schwartz GG, Wang L, et al. (2004) The prostate 25-hydroxyvitamin D-1 alpha-hydroxylase is not influenced by parathyroid hormone and calcium: implications for prostate cancer chemoprevention by vitamin D. Carcinogenesis $\mathbf{2 5}$, 967-971.

11. Pike JW \& Meyer MB (2012) Regulation of mouse Cyp24a1 expression via promoter-proximal and downstream-distal enhancers highlights new concepts of 1,25-dihydroxyvitamin D(3) action. Arch Biochem Biophys 523, 2-8.

12. Christakos S, Dhawan P, Verstuyf A, et al. (2016) Vitamin D: metabolism, molecular mechanism of action, and pleiotropic effects. Physiol Rev 96, 365-408. 
13. Carlberg C, Bendik I, Wyss A, et al. (1993) Two nuclear signalling pathways for vitamin D. Nature 361, 657-660.

14. Tagami T, Lutz WH, Kumar R, et al. (1998) The interaction of the vitamin D receptor with nuclear receptor corepressors and coactivators. Biochem Biophys Res Commun 253, 358-363.

15. Murayama A, Kim MS, Yanagisawa J, et al. (2004) Transrepression by a liganded nuclear receptor via a bHLH activator through co-regulator switching. EMBO J 23, 1598-1608.

16. Kim MS, Fujiki R, Murayama A, et al. (2007) 1Alpha,25(OH) $2 \mathrm{D}_{3}$-induced transrepression by vitamin $\mathrm{D}$ receptor through E-box-type elements in the human parathyroid hormone gene promoter. Mol Endocrinol 21, 334-342.

17. Haussler MR, Whitfield GK, Kaneko I, et al. (2013) Molecular mechanisms of vitamin D action. Calcif Tissue Int 92, 77-98.

18. Haussler MR, Jurutka PW, Mizwicki M, et al. (2011) Vitamin D receptor (VDR)-mediated actions of 1alpha,25(OH)(2)vitamin D(3): genomic and non-genomic mechanisms. Best Pract Res Clin Endocrinol Metab 25, 543-559.

19. Norman AW, Mizwicki MT \& Norman DP (2004) Steroidhormone rapid actions, membrane receptors and a conformational ensemble model. Nat Rev Drug Discov 3, 27-41.

20. Ordonez-Moran P, Larriba MJ, Palmer HG, et al. (2008) RhoA-ROCK and p38MAPK-MSK1 mediate vitamin D effects on gene expression, phenotype, and Wnt pathway in colon cancer cells. J Cell Biol 183, 697-710.

21. Hsu JY, Feldman D, McNeal JE, et al. (2001) Reduced 1alphahydroxylase activity in human prostate cancer cells correlates with decreased susceptibility to 25-hydroxyvitamin $\mathrm{D}_{3^{-}}$ induced growth inhibition. Cancer Res 61, 2852-2856.

22. Swami S, Krishnan AV, Wang JY, et al. (2012) Dietary vitamin $\mathrm{D}(3)$ and 1,25-dihydroxyvitamin $\mathrm{D}(3)$ (calcitriol) exhibit equivalent anticancer activity in mouse xenograft models of breast and prostate cancer. Endocrinology 153, 2576-2587.

23. Zehnder D, Bland R, Williams MC, et al. (2001) Extrarenal expression of 25-hydroxyvitamin d(3)-1 alpha-hydroxylase. J Clin Endocrinol Metab 86, 888-894.

24. Cross HS, Bises G, Lechner D, et al. (2005) The vitamin D endocrine system of the gut - its possible role in colorectal cancer prevention. J Steroid Biochem Mol Biol 97, 121-128.

25. Bises G, Kallay E, Weiland T, et al. (2004) 25-Hydroxyvitamin $\mathrm{D}_{3}$-1alpha-hydroxylase expression in normal and malignant human colon. J Histochem Cytochem 52, 985-989.

26. Tangpricha V, Flanagan JN, Whitlatch LW, et al. (2001) 25-Hydroxyvitamin D-1 alpha-hydroxylase in normal and malignant colon tissue. Lancet 357, 1673-1674.

27. Cross HS, Bareis P, Hofer H, et al. (2001) 25-Hydroxyvitamin $\mathrm{D}(3)$-1alpha-hydroxylase and vitamin $\mathrm{D}$ receptor gene expression in human colonic mucosa is elevated during early cancerogenesis. Steroids 66, 287-292.

28. Bareis P, Bises G, Bischof MG, et al. (2001) 25-Hydroxyvitamin D metabolism in human colon cancer cells during tumor progression. Biochem Biophys Res Commun 285, 1012-1017.

29. Ogunkolade BW, Boucher BJ, Fairclough PD, et al. (2002) Expression of 25-hydroxyvitamin D-1- $\alpha$-hydroxylase mRNA in individuals with colorectal cancer. Lancet 359, 1831-1832.

30. Bareis P, Kallay E, Bischof MG, et al. (2002) Clonal differences in expression of 25-hydroxyvitamin D(3)-1alphahydroxylase, of 25-hydroxyvitamin D(3)-24-hydroxylase, and of the vitamin $\mathrm{D}$ receptor in human colon carcinoma cells: effects of epidermal growth factor and 1alpha, 25-dihydroxyvitamin D(3). Exp Cell Res 276, 320-327.

31. Holt PR, Arber N, Halmos B, et al. (2002) Colonic epithelial cell proliferation decreases with increasing levels of serum 25-hydroxy vitamin D. Cancer Epidemiol Biomarkers Prev 11, 113-119.

32. Wagner D, Dias AG, Schnabl K, et al. (2012) Determination of 1,25-dihydroxyvitamin D concentrations in human colon tissues and matched serum samples. Anticancer Res 32, 259-263.

33. Horvath HC, Lakatos P, Kosa JP, et al. (2010) The candidate oncogene CYP24A1: a potential biomarker for colorectal tumorigenesis. J Histochem Cytochem 58, 277-285.

34. Anderson MG, Nakane M, Ruan X, et al. (2006) Expression of VDR and CYP24A1 mRNA in human tumors. Cancer Chemother Pharmacol 57, 234-240.

35. Kosa JP, Horvath P, Wolfling J, et al. (2013) CYP24A1 inhibition facilitates the anti-tumor effect of vitamin $\mathrm{D}_{3}$ on colorectal cancer cells. World J Gastroenterol 19, 2621-2628.

36. Wang Y, Zhu J \& DeLuca HF (2012) Where is the vitamin D receptor? Arch Biochem Biophys 523, 123-133.

37. Matusiak D, Murillo G, Carroll RE, et al. (2005) Expression of vitamin $\mathrm{D}$ receptor and 25-hydroxyvitamin $\mathrm{D}_{3}$-1\{alpha\}hydroxylase in normal and malignant human colon. Cancer Epidemiol Biomarkers Prev 14, 2370-2376.

38. Palmer HG, Larriba MJ, Garcia JM, et al. (2004) The transcription factor SNAIL represses vitamin D receptor expression and responsiveness in human colon cancer. Nat Med 10, 917-919.

39. Larriba MJ, Bonilla F \& Munoz A (2010) The transcription factors Snail1 and Snail2 repress vitamin D receptor during colon cancer progression. J Steroid Biochem Mol Biol 121, 106-109.

40. Ramagopalan SV, Heger A, Berlanga AJ, et al. (2010) A ChIP-seq defined genome-wide map of vitamin D receptor binding: associations with disease and evolution. Genome Res 20, 1352-1360.

41. Meyer MB, Goetsch PD \& Pike JW (2012) VDR-RXR and TCF4/beta-catenin cistromes in colonic cells of colorectal tumor origin: impact on c-FOS and c-MYC gene expression. Mol Endocrinol 26, 37-51.

42. Goeman F, De Nicola F, D'Onorio De Meo P, et al. (2014) VDR primary targets by genome-wide transcriptional profiling. J Steroid Biochem Mol Biol 143, 348-356.

43. Shabahang M, Buras RR, Davoodi F, et al. (1993) 1,25-Dihydroxyvitamin $\mathrm{D}_{3}$ receptor as a marker of human colon carcinoma cell line differentiation and growth inhibition. Cancer Res 53, 3712-3718.

44. Scaglione-Sewell BA, Bissonnette M, Skarosi S, et al. (2000) A vitamin $\mathrm{D}_{3}$ analog induces a G1-phase arrest in CaCo-2 cells by inhibiting cdk2 and cdk6: roles of cyclin E, p21Waf1, and p27Kip1. Endocrinology 141, 3931-3939.

45. Gaschott T, Steinmeyer A, Steinhilber D, et al. (2002) ZK 156718, a low calcemic, antiproliferative, and prodifferentiating vitamin D analog. Biochem Biophys Res Commun 290, 504-509.

46. Berkovich L, Sintov AC \& Ben-Shabat S (2013) Inhibition of cancer growth and induction of apoptosis by BGP-13 and BGP-15, new calcipotriene-derived vitamin $\mathrm{D}_{3}$ analogs, in-vitro and in-vivo studies. Invest New Drugs 31, 247-255.

47. Chen AP, Davis BH, Sitrin MD, et al. (2002) Transforming growth factor-beta 1 signaling contributes to Caco-2 cell growth inhibition induced by $1,25(\mathrm{OH})(2) \mathrm{D}-3$. Am J Physiol Gastrointest Liver Physiol 283, G864-G874.

48. Oh YS, Kim EJ, Schaffer BS, et al. (2001) Synthetic lowcalcaemic vitamin $\mathrm{D}(3)$ analogues inhibit secretion of insulin-like growth factor II and stimulate production of insulin-like growth factor-binding protein- 6 in conjunction with growth suppression of HT-29 colon cancer cells. Mol Cell Endocrinol 183, 141-149. 
49. Tong WM, Hofer H, Ellinger A, et al. (1999) Mechanism of antimitogenic action of vitamin D in human colon carcinoma cells: relevance for suppression of epidermal growth factor-stimulated cell growth. Oncol Res 11, 77-84.

50. Diaz GD, Paraskeva C, Thomas MG, et al. (2000) Apoptosis is induced by the active metabolite of vitamin $\mathrm{D}_{3}$ and its analogue EB1089 in colorectal adenoma and carcinoma cells: possible implications for prevention and therapy. Cancer Res 60, 2304-2312.

51. Chen A, Davis BH, Bissonnette M, et al. (1999) 1,25Dihydroxyvitamin D(3) stimulates activator protein-1-dependent Caco-2 cell differentiation. J Biol Chem 274, 35505-35513.

52. Palmer HG, Gonzalez-Sancho JM, Espada J, et al. (2001) Vitamin D-3 promotes the differentiation of colon carcinoma cells by the induction of E-cadherin and the inhibition of beta-catenin signaling. J Cell Biol 154, 369-387.

53. Palmer HG, Sanchez-Carbayo M, Ordonez-Moran P, et al. (2003) Genetic signatures of differentiation induced by 1alpha,25-dihydroxyvitamin $\mathrm{D}_{3}$ in human colon cancer cells. Cancer Res 63, 7799-7806.

54. $\mathrm{Xu} \mathrm{H}$, Posner GH, Stevenson M, et al. (2010) Apc(MIN) modulation of vitamin D secosteroid growth control. Carcinogenesis 31, 1434-1441.

55. Egan JB, Thompson PA, Vitanov MV, et al. (2010) Vitamin D receptor ligands, adenomatous polyposis coli, and the vitamin $\mathrm{d}$ receptor FokI polymorphism collectively modulate beta-catenin activity in colon cancer cells. Mol Carcinog 49, 337-352.

56. Aguilera O, Pena C, Garcia JM, et al. (2007) The Wnt antagonist DICKKOPF-1 gene is induced by 1alpha, 25-dihydroxyvitamin $\mathrm{D}_{3}$ associated to the differentiation of human colon cancer cells. Carcinogenesis 28, 1877-1884.

57. Barnes JD, Arhel NJ, Lee SS, et al. (2005) Nuclear BAG-1 expression inhibits apoptosis in colorectal adenoma-derived epithelial cells. Apoptosis 10, 301-311.

58. Liu G, Hu X \& Chakrabarty S (2010) Vitamin D mediates its action in human colon carcinoma cells in a calcium-sensing receptor-dependent manner: downregulates malignant cell behavior and the expression of thymidylate synthase and survivin and promotes cellular sensitivity to 5-FU. Int $J$ Cancer 126, 631-639.

59. Canaff L \& Hendy GN (2002) Human calcium-sensing receptor gene. Vitamin D response elements in promoters $\mathrm{P} 1$ and P2 confer transcriptional responsiveness to 1,25dihydroxyvitamin D. J Biol Chem 277, 30337-30350.

60. Chakrabarty S, Wang HM, Canaff L, et al. (2005) Calcium sensing receptor in human colon carcinoma: interaction with $\mathrm{Ca}^{2+}$ and 1,25-dihydroxyvitamin D-3. Cancer Res $\mathbf{6 5}$, 493-498.

61. Yang K, Lamprecht SA, Shinozaki H, et al. (2008) Dietary calcium and cholecalciferol modulate cyclin D1 expression, apoptosis, and tumorigenesis in intestine of adenomatous polyposis coli1638N/ + mice. J Nutr 138, 1658-1663.

62. Stambolsky P, Tabach Y, Fontemaggi G, et al. (2010) Modulation of the vitamin $D_{3}$ response by cancer-associated mutant p53. Cancer Cell 17, 273-285.

63. Mantell DJ, Owens PE, Bundred NJ, et al. (2000) 1 alpha, 25-Dihydroxyvitamin $\mathrm{D}(3)$ inhibits angiogenesis in vitro and in vivo. Circ Res 87, 214-220.

64. Ben-Shoshan M, Amir S, Dang DT, et al. (2007) 1 alpha, 25-Dihydroxyvitamin D-3 (calcitriol) inhibits hypoxia-inducible factor-1/vascular endothelial growth factor pathway in human cancer cells. Mol Cancer Ther 6, 1433-1439.

65. Fernandez-Garcia NI, Palmer HG, Garcia M, et al. (2005) 1 alpha, 25-Dihydroxyvitamin D-3 regulates the expression of Id1 and Id2 genes and the angiogenic phenotype of human colon carcinoma cells. Oncogene 24, 6533-6544.
66. Pendas-Franco N, Garcia JM, Pena C, et al. (2008) DICKKOPF-4 is induced by TCF/beta-catenin and upregulated in human colon cancer, promotes tumour cell invasion and angiogenesis and is repressed by 1alpha,25-dihydroxy vitamin $\mathrm{D}_{3}$. Oncogene 27, 4467-4477.

67. Iseki K, Tatsuta M, Uehara H, et al. (1999) Inhibition of angiogenesis as a mechanism for inhibition by 1alphahydroxyvitamin $\mathrm{D}_{3}$ and 1,25-dihydroxyvitamin $\mathrm{D}_{3}$ of colon carcinogenesis induced by azoxymethane in Wistar rats. Int J Cancer 81, 730-733.

68. van Harten-Gerritsen AS, Balvers MG, Witkamp RF, et al. (2015) Vitamin D, inflammation and colorectal cancer progression: a review of mechanistic studies and future directions for epidemiological studies. Cancer Epidemiol Biomarkers Prev 24, 1820-1828.

69. Gombart AF, Borregaard N \& Koeffler HP (2005) Human cathelicidin antimicrobial peptide (CAMP) gene is a direct target of the vitamin $\mathrm{D}$ receptor and is strongly up-regulated in myeloid cells by 1,25-dihydroxyvitamin D-3. FASEB J 19, 1067-1077.

70. Sun J, Mustafi R, Cerda S, et al. (2008) Lithocholic acid down-regulation of NF-kappa B activity through vitamin D receptor in colonic cancer cells. J Steroid Biochem Mol Biol 111, 37-40.

71. Liu N, Nguyen L, Chun RF, et al. (2008) Altered endocrine and autocrine metabolism of vitamin $\mathrm{D}$ in a mouse model of gastrointestinal inflammation. Endocrinology 149, 4799-4808

72. Meeker S, Seamons A, Paik J, et al. (2014) Increased dietary vitamin D suppresses MAPK signaling, colitis, and colon cancer. Cancer Res 74, 4398-4408.

73. Veldhoen M \& Brucklacher-Waldert V (2012) Dietary influences on intestinal immunity. Nat Rev Immunol 12, 696-708.

74. Bruce D \& Cantorna MT (2011) Intrinsic requirement for the vitamin $\mathrm{D}$ receptor in the development of CD8alphaalphaexpressing T cells. J Immunol 186, 2819-2825.

75. van Wijk F \& Cheroutre H (2009) Intestinal T cells: facing the mucosal immune dilemma with synergy and diversity. Semin Immunol 21, 130-138.

76. Wada K, Tanaka H, Maeda K, et al. (2009) Vitamin D receptor expression is associated with colon cancer in ulcerative colitis. Oncol Rep 22, 1021-1025.

77. Hummel DM, Fetahu IS, Groschel C, et al. (2014) Role of proinflammatory cytokines on expression of vitamin D metabolism and target genes in colon cancer cells. J Steroid Biochem Mol Biol 144, 91-95.

78. Johnson CH, Dejea CM, Edler D, et al. (2015) Metabolism links bacterial biofilms and colon carcinogenesis. Cell Metab 21, 891-897.

79. Mima K, Sukawa Y, Nishihara R, et al. (2015) Fusobacterium nucleatum and T cells in colorectal carcinoma. JAMA Oncol 1, 653-661.

80. O'Keefe SJ, Li JV, Lahti L, et al. (2015) Fat, fibre and cancer risk in African Americans and rural Africans. Nat Commun 6, 6342

81. Lagishetty V, Misharin AV, Liu NQ, et al. (2010) Vitamin D deficiency in mice impairs colonic antibacterial activity and predisposes to colitis. Endocrinology 151, 2423-2432.

82. Ooi JH, Li Y, Rogers CJ, et al. (2013) Vitamin D regulates the gut microbiome and protects mice from dextran sodium sulfate-induced colitis. J Nutr 143, 1679-1686.

83. Alvarez-Diaz S, Valle N, Ferrer-Mayorga G, et al. (2012) MicroRNA-22 is induced by vitamin D and contributes to its antiproliferative, antimigratory and gene regulatory effects in colon cancer cells. Hum Mol Genet 21, 2157-2165. 
84. Padi SK, Zhang Q, Rustum YM, et al. (2013) MicroRNA-627 mediates the epigenetic mechanisms of vitamin D to suppress proliferation of human colorectal cancer cells and growth of xenograft tumors in mice. Gastroenterology $\mathbf{1 4 5}$, 437-446.

85. Newmark HL, Yang K, Kurihara N, et al. (2009) Westernstyle diet-induced colonic tumors and their modulation by calcium and vitamin $\mathrm{D}$ in $\mathrm{C} 57 \mathrm{Bl} / 6$ mice: a preclinical model for human sporadic colon cancer. Carcinogenesis $\mathbf{3 0}$, 88-92.

86. Mokady E, Schwartz B, Shany S, et al. (2000) A protective role of dietary vitamin $\mathrm{D}_{3}$ in rat colon carcinogenesis. Nutr Cancer 38, 65-73.

87. Hummel DM, Thiem U, Hobaus J, et al. (2013) Prevention of preneoplastic lesions by dietary vitamin D in a mouse model of colorectal carcinogenesis. J Steroid Biochem Mol Biol 136, 284-288.

88. Tangpricha V, Spina C, Yao M, et al. (2005) Vitamin D deficiency enhances the growth of MC-26 colon cancer xenografts in Balb/c mice. J Nutr 135, 2350-2354.

89. Milczarek M, Psurski M, Kutner A, et al. (2013) Vitamin D analogs enhance the anticancer activity of 5-fluorouracil in an in vivo mouse colon cancer model. BMC Cancer 13, 294.

90. Milczarek M, Rosinska S, Psurski M, et al. (2013) Combined colonic cancer treatment with vitamin D analogs and irinotecan or oxaliplatin. Anticancer Res 33, 433-444.

91. Huerta S, Irwin RW, Heber D, et al. (2002) 1 alpha,25-(OH) (2)-D-3 and its synthetic analogue decrease tumor load in the Apc(min) mouse. Cancer Res 62, 741-746.

92. Kallay E, Pietschmann P, Toyokuni S, et al. (2001) Characterization of a vitamin $\mathrm{D}$ receptor knockout mouse as a model of colorectal hyperproliferation and DNA damage. Carcinogenesis 22, 1429-1435.

93. Jesus Larriba M, Ordonez-Moran P, Chicote I, et al. (2011). Vitamin D receptor deficiency enhances Wnt/beta-catenin signaling and tumor burden in colon cancer. PLOS ONE $\mathbf{6}$, e23524.

94. Bostick RM (2015) Effects of supplemental vitamin D and calcium on normal colon tissue and circulating biomarkers of risk for colorectal neoplasms. J Steroid Biochem Mol Biol 148, 86-95.

95. Fedirko V, Bostick RM, Flanders WD, et al. (2009) Effects of vitamin D and calcium supplementation on markers of apoptosis in normal colon mucosa: a randomized, double-blind, placebo-controlled clinical trial. Cancer Prev Res 2, 213-223.

96. Fedirko V, Bostick RM, Flanders WD, et al. (2009) Effects of vitamin $\mathrm{d}$ and calcium on proliferation and differentiation in normal colon mucosa: a randomized clinical trial. Cancer Epidemiol Biomarkers Prev 18, 2933-2941.

97. Ahearn TU, Shaukat A, Flanders WD, et al. (2012) A randomized clinical trial of the effects of supplemental calcium and vitamin $\mathrm{D}_{3}$ on the APC/beta-catenin pathway in the normal mucosa of colorectal adenoma patients. Cancer Prev Res 5, 1247-1256.

98. Sidelnikov E, Bostick RM, Flanders WD, et al. (2010) Effects of calcium and vitamin D on MLH1 and MSH2 expression in rectal mucosa of sporadic colorectal adenoma patients. Cancer Epidemiol Biomarkers Prev 19, 1022-1032.

99. Ahearn TU, McCullough ML, Flanders WD, et al. (2011) A randomized clinical trial of the effects of supplemental calcium and vitamin $\mathrm{D}_{3}$ on markers of their metabolism in normal mucosa of colorectal adenoma patients. Cancer Res 71, 413-423.

100. Holick MF (2007) Vitamin D deficiency. N Engl J Med 357, 266-281.

101. Ross AC, Manson JE, Abrams SA, et al. (2011) The 2011 report on dietary reference intakes for calcium and vitamin D from the Institute of Medicine: what clinicians need to know. $J$ Clin Endocrinol Metab 96, 53-58.

102. Davis CD \& Dwyer JT (2007) The 'sunshine vitamin': benefits beyond bone? J Natl Cancer Inst 99, 1563-1565.

103. Autier P, Boniol M, Pizot C, et al. (2014) Vitamin D status and ill health: a systematic review. Lancet Diabetes Endocrinol 2, 76-89.

104. Song M, Wu K, Chan AT, et al. (2014) Plasma 25-hydroxyvitamin D and risk of colorectal cancer after adjusting for inflammatory markers. Cancer Epidemiol Biomarkers Prev 23, 2175-2180.

105. Hofmann JN, Yu K, Horst RL, et al. (2010) Long-term variation in serum 25-hydroxyvitamin D concentration among participants in the Prostate, Lung, Colorectal, and Ovarian Cancer Screening Trial. Cancer Epidemiol Biomarkers Prev 19, 927-931.

106. Grant WB (2011) Effect of interval between serum draw and follow-up period on relative risk of cancer incidence with respect to 25-hydroxyvitamin D level: implications for metaanalyses and setting vitamin D guidelines. Dermatoendocrinol 3, 199-204.

107. Cheng TY, Millen AE, Wactawski-Wende J, et al. (2014) Vitamin D intake determines vitamin $d$ status of postmenopausal women, particularly those with limited sun exposure. J Nutr 144, 681-689.

108. Bertrand KA, Giovannucci E, Liu Y, et al. (2012) Determinants of plasma 25-hydroxyvitamin $\mathrm{D}$ and development of prediction models in three US cohorts. Br J Nutr $\mathbf{1 0 8}$, 1889-1896.

109. Jung S, Qian ZR, Yamauchi M, et al. (2014) Predicted 25(OH)D score and colorectal cancer risk according to vitamin D receptor expression. Cancer Epidemiol Biomarkers Prev 23, $1628-1637$.

110. Wactawski-Wende J, Kotchen JM, Anderson GL, et al. (2006) Calcium plus vitamin D supplementation and the risk of colorectal cancer. N Engl J Med 354, 684-696.

111. Wu K, Feskanich D, Fuchs CS, et al. (2007) A nested case-control study of plasma 25-hydroxyvitamin D concentrations and risk of colorectal cancer. J Natl Cancer Inst 99, 1120-1129.

112. Otani T, Iwasaki M, Sasazuki S, et al. (2007) Plasma vitamin D and risk of colorectal cancer: the Japan Public Health Center-Based Prospective Study. Br J Cancer 97, 446-451.

113. Jenab M, Bueno-de-Mesquita HB, Ferrari P, et al. (2010) Association between pre-diagnostic circulating vitamin D concentration and risk of colorectal cancer in European populations:a nested case-control study. BMJ 340, b5500.

114. Lee JE, Li H, Chan AT, et al. (2011) Circulating levels of vitamin D and colon and rectal cancer: the Physicians' Health Study and a Meta-analysis of Prospective Studies. Cancer Prev Res 4, 735-743.

115. Ma Y, Zhang P, Wang F, et al. (2011) Association between vitamin D and risk of colorectal cancer: a systematic review of prospective studies. J Clin Oncol 29, 3775-3782.

116. Chung M, Lee J, Terasawa T, et al. (2011) Vitamin D with or without calcium supplementation for prevention of cancer and fractures: an updated meta-analysis for the U.S. Preventive Services Task Force. Ann Inter Med 155, 827-838.

117. Neuhouser ML, Manson JE, Millen A, et al. (2012) The influence of health and lifestyle characteristics on the relation of serum 25-hydroxyvitamin D with risk of colorectal and breast cancer in postmenopausal women. Am J Epidemiol 175, 673-684.

118. English DR, Williamson EJ, Heath AK, et al. (2013) Abstract A54: vitamin D and risk of colorectal cancer: the Melbourne Collaborative Cohort Study. Cancer Prev Res 6, A54. 
119. Anic GM, Weinstein SJ, Mondul AM, et al. (2014) Serum vitamin $\mathrm{D}$, vitamin $\mathrm{D}$ binding protein, and risk of colorectal cancer. PLOS ONE 9, e102966.

120. Theodoratou E, Tzoulaki I, Zgaga L, et al. (2014) Vitamin D and multiple health outcomes: umbrella review of systematic reviews and meta-analyses of observational studies and randomised trials. BMJ 348, g2035.

121. Weinstein SJ, Purdue MP, Smith-Warner SA, et al. (2015) Serum 25-hydroxyvitamin $\mathrm{D}$, vitamin $\mathrm{D}$ binding protein and risk of colorectal cancer in the Prostate, Lung, Colorectal and Ovarian Cancer Screening Trial. Int J Cancer 136, E654-E664.

122. Song $M$, Nishihara $R$, Wang $M$, et al. (2015) Plasma 25-hydroxyvitamin D and colorectal cancer risk according to tumour immunity status. Gut 65, 269-304.

123. Lee JE (2011) Circulating levels of vitamin D, vitamin D receptor polymorphisms, and colorectal adenoma: a meta-analysis. Nutr Res Pract 5, 464-470.

124. Yin L, Grandi N, Raum E, et al. (2011) Meta-analysis: serum vitamin D and colorectal adenoma risk. Preven Med 53, 10-16.

125. Ogino S, Lochhead P, Chan AT, et al. (2013) Molecular pathological epidemiology of epigenetics: emerging integrative science to analyze environment, host, and disease. Mod Pathol 26, 465-484.

126. Ogino S, Campbell PT, Nishihara R, et al. (2015) Proceedings of the second international molecular pathological epidemiology (MPE) meeting. Cancer Causes Control 26, 959-972.

127. Wang M, Kuchiba A \& Ogino S (2015) A meta-regression method for studying etiological heterogeneity across disease subtypes classified by multiple biomarkers. Am J Epidemiol 182, 263-270.

128. Wang M, Spiegelman D, Kuchiba A, et al. (2015) Statistical methods for studying disease subtype heterogeneity. Stat Med 35, 782-800.

129. Edfeldt K, Liu PT, Chun R, et al. (2010) T-cell cytokines differentially control human monocyte antimicrobial responses by regulating vitamin D metabolism. Proc Natl Acad Sci U S A 107, 22593-22598.

130. Liu PT, Stenger S, Li H, et al. (2006) Toll-like receptor triggering of a vitamin D-mediated human antimicrobial response. Science 311, 1770-1773.

131. Sigmundsdottir H, Pan J, Debes GF, et al. (2007) DCs metabolize sunlight-induced vitamin $\mathrm{D}_{3}$ to 'program' $\mathrm{T}$ cell attraction to the epidermal chemokine CCL27. Nat Immunol $\mathbf{8}, 285-293$.

132. Nishihara R, VanderWeele TJ, Shibuya K, et al. (2015) Molecular pathological epidemiology gives clues to paradoxical findings. Eur J Epidemiol 30, 1129-1135.

133. Ng K, Meyerhardt JA, Wu K, et al. (2008) Circulating 25-hydroxyvitamin D levels and survival in patients with colorectal cancer. J Clin Oncol 26, 2984-2991.

134. Ng K, Wolpin BM, Meyerhardt JA, et al. (2009) Prospective study of predictors of vitamin D status and survival in patients with colorectal cancer. $B r J$ Cancer 101, 916-923.

135. Ng K, Sargent DJ, Goldberg RM, et al. (2011) Vitamin D status in patients with stage IV colorectal cancer: findings from Intergroup trial N9741. J Clin Oncol 29, 1599-1606.

136. Fedirko V, Riboli E, Tjonneland A, et al. (2012) Prediagnostic 25-hydroxyvitamin D, VDR and CASR polymorphisms, and survival in patients with colorectal cancer in western European populations. Cancer Epidemiol Biomarkers Prev 21, 582-593.

137. Zgaga L, Theodoratou E, Farrington SM, et al. (2014) Plasma vitamin D concentration influences survival outcome after a diagnosis of colorectal cancer. I Clin Oncol 32 , 2430-2439.

138. Maalmi H, Ordonez-Mena JM, Schottker B, et al. (2014) Serum 25-hydroxyvitamin D levels and survival in colorectal and breast cancer patients: systematic review and metaanalysis of prospective cohort studies. Eur J Cancer 50, $1510-1521$.

139. Ng K, Venook AP, Sato K, et al. (2015) Vitamin D status and survival of metastatic colorectal cancer patients: results from CALGB/SWOG 80405 (alliance). J Clin Oncol 33, Suppl. 3, 507.

140. Martinez ME, Giovannucci EL, Colditz GA, et al. (1996) Calcium, vitamin $\mathrm{D}$, and the occurrence of colorectal cancer among women. J Natl Cancer Inst 88, 1375-1382.

141. Pritchard RS, Baron JA \& deVerdier MG (1996) Dietary calcium, vitamin D, and the risk of colorectal cancer in Stockholm, Sweden. Cancer Epidemiol Biomarkers Prev $\mathbf{5}$, 897-900.

142. Terry P, Baron JA, Bergkvist L, et al. (2002) Dietary calcium and vitamin D intake and risk of colorectal cancer: a prospective cohort study in women. Nutr Cancer 43, 39-46.

143. Slattery ML, Neuhausen SL, Hoffman M, et al. (2004) Dietary calcium, vitamin D, VDR genotypes and colorectal cancer. Int J Cancer 111, 750-756.

144. Park SY, Murphy SP, Wilkens LR, et al. (2007) Calcium and vitamin D intake and risk of colorectal cancer: the Multiethnic Cohort Study. Am J Epidemiol 165, 784-793.

145. Mizoue T, Kimura Y, Toyomura K, et al. (2008) Calcium, dairy foods, vitamin $\mathrm{D}$, and colorectal cancer risk: the Fukuoka Colorectal Cancer Study. Cancer Epidemiol Biomarkers Prev 17, 2800-2807.

146. Ishihara J, Inoue M, Iwasaki M, et al. (2008) Dietary calcium, vitamin D, and the risk of colorectal cancer. Am J Clin Nutr 88, 1576-1583.

147. Lipworth L, Bender TJ, Rossi M, et al. (2009) Dietary vitamin D intake and cancers of the colon and rectum: a case-control study in Italy. Nutr Cancer 61, 70-75.

148. Huncharek M, Muscat J \& Kupelnick B (2009) Colorectal cancer risk and dietary intake of calcium, vitamin $\mathrm{D}$, and dairy products: a meta-analysis of 26335 cases from 60 observational studies. Nutr Cancer 61, 47-69.

149. Marcus PM \& Newcomb PA (1998) The association of calcium and vitamin $\mathrm{D}$, and colon and rectal cancer in Wisconsin women. Int J Epidemiol 27, 788-793.

150. McCullough ML, Robertson AS, Rodriguez C, et al. (2003) Calcium, vitamin D, dairy products, and risk of colorectal cancer in the Cancer Prevention Study II Nutrition Cohort (United States). Cancer Causes Control 14, 1-12.

151. Yang B, McCullough ML, Gapstur SM, et al. (2014) Calcium, vitamin $\mathrm{D}$, dairy products, and mortality among colorectal cancer survivors: the Cancer Prevention Study-II Nutrition Cohort. J Clin Oncol 32, 2335-2343.

152. Trivedi DP, Doll R \& Khaw KT (2003) Effect of four monthly oral vitamin D-3 (cholecalciferol) supplementation on fractures and mortality in men and women living in the community: randomised double blind controlled trial. BMJ 326, 469-472.

153. Lappe JM, Travers-Gustafson D, Davies KM, et al. (2007) Vitamin D and calcium supplementation reduces cancer risk: results of a randomized trial. Am J Clin Nutr 85, 1586-1591.

154. Avenell A, MacLennan GS, Jenkinson DJ, et al. (2012) Longterm follow-up for mortality and cancer in a randomized placebo-controlled trial of vitamin $\mathrm{D}(3)$ and/or calcium (RECORD trial). J Clin Endocrinol Metab 97, 614-622.

155. Ng K, Scott JB, Drake BF, et al. (2014) Dose response to vitamin D supplementation in African Americans: results of a 
4-arm, randomized, placebo-controlled trial. Am J Clin Nutr 99, 587-598.

156. Bolland MJ, Grey A, Gamble GD, et al. (2011) Calcium and vitamin D supplements and health outcomes: a reanalysis of the Women's Health Initiative (WHI) limited-access data set. Am J Clin Nutr 94, 1144-1149.

157. Baron JA, Barry EL, Mott LA, et al. (2015) A trial of calcium and vitamin $\mathrm{D}$ for the prevention of colorectal adenomas. $N$ Engl J Med 373, 1519-1530.

158. Bischoff-Ferrari HA, Giovannucci E, Willett WC, et al. (2006) Estimation of optimal serum concentrations of 25-hydroxyvitamin D for multiple health outcomes. Am J Clin Nutr 84, 18-28.

159. Bischoff-Ferrari HA, Shao A, Dawson-Hughes B, et al. (2010) Benefit-risk assessment of vitamin D supplementation. Osteoporos Int 21, 1121-1132.

160. Giovannucci E (2013) Epidemiology of vitamin D and colorectal cancer. Anticancer Agents Med Chem 13, 11-19.

161. Kunzmann AT, Coleman HG, Huang WY, et al. (2015) Dietary fiber intake and risk of colorectal cancer and incident and recurrent adenoma in the Prostate, Lung, Colorectal, and Ovarian Cancer Screening Trial. Am J Clin Nutr 102, 881-890.

162. Manson JE \& Bassuk SS (2015) Vitamin D research and clinical practice: at a crossroads. JAMA 313, 1311-1312.

163. Pradhan AD \& Manson JE (2015) Update on the Vitamin D and OmegA-3 trial (VITAL). J Steroid Biochem Mol Biol 155 252-256.

164. Lichtenstein P, Holm NV, Verkasalo PK, et al. (2000) Environmental and heritable factors in the causation of cancer - analyses of cohorts of twins from Sweden, Denmark, and Finland. $N$ Engl J Med 343, 78-85.

165. Shea M, Benjamin E, Dupuis J, et al. (2009) Genetic and non-genetic correlates of vitamins K and D. Eur J Clin Nutr 63, 458-464.
166. Wang TJ, Zhang F, Richards JB, et al. (2010) Common genetic determinants of vitamin D insufficiency: a genome-wide association study. Lancet 376, 180-188.

167. Hiraki LT, Qu C, Hutter CM, et al. (2013) Genetic predictors of circulating 25-hydroxyvitamin $\mathrm{d}$ and risk of colorectal cancer. Cancer Epidemiol Biomarkers Prev 22, 2037-2046.

168. Jorde R, Schirmer H, Wilsgaard T, et al. (2012) Polymorphisms related to the serum 25-hydroxyvitamin D level and risk of myocardial infarction, diabetes, cancer and mortality. The Tromso Study. PLOS ONE 7, e37295.

169. Peters U, Bien S \& Zubair N (2015) Genetic architecture of colorectal cancer. Gut 64, 1623-1636.

170. Koestner K, Denzer N, Mueller CSL, et al. (2009) The relevance of vitamin $\mathrm{D}$ receptor (VDR) gene polymorphisms for cancer: a review of the literature. Anticancer Res 29, 3511-3536.

171. Touvier M, Chan DSM, Lau R, et al. (2011) Meta-analyses of vitamin D intake, 25-hydroxyvitamin D status, vitamin D receptor polymorphisms, and colorectal cancer risk. Cancer Epidemiol Biomarkers Prev 20, 1003-1016.

172. Serrano D, Gnagnarella P, Raimondi S, et al. (2015) Metaanalysis on vitamin D receptor and cancer risk: focus on the role of TaqI, ApaI, and Cdx2 polymorphisms. Eur J Cancer Prev 25, 85-96.

173. Hiraki LT, Joshi AD, Ng K, et al. (2014) Joint effects of colorectal cancer susceptibility loci, circulating 25hydroxyvitamin D and risk of colorectal cancer. PLOS ONE 9, e92212.

174. Ferguson LR, Laing B, Marlow G, et al. (2015) The role of vitamin $\mathrm{D}$ in reducing gastrointestinal disease risk and assessment of individual dietary intake needs: focus on genetic and genomic technologies. Mol Nutr Food Res 60, 119-133. 